\title{
Ferrocyanide Safety Program Cyanide Speciation Studies Final Report
}

\author{
S. A. Bryan \\ K. H. Pool \\ S. L. Bryan \\ S. V. Forbes \\ F. V. Hoopes \\ B. D. Lerner \\ G. M. Mong \\ P. T. Nguyen \\ G. F. Schiefelbein \\ R. L. Sell \\ L. M. P. Thomas
}

July 1995

Prepared for

the U.S. Department of Energy

under Contract DE-AC06-76RLO 1830

Pacific Northwest Laboratory

Richland, Washington 99352 


\section{DISCLAIMER}

This report was prepared as an account of work sponsored by an agency of the United States Government. Neither the United States Government nor any agency thereof, nor any of their employees, make any warranty, express or implied, or assumes any legal liability or responsibility for the accuracy, completeness, or usefulness of any information, apparatus, product, or process disclosed, or represents that its use would not infringe privately owned rights. Reference herein to any specific commercial product, process, or service by trade name, trademark, manufacturer, or otherwise does not necessarily constitute or imply its endorsement, recommendation, or favoring by the United States Government or any agency thereof. The views and opinions of authors expressed herein do not necessarily state or reflect those of the United States Government or any agency thereof. 


\section{DISCLAIMER}

Portions of this document may be illegible in electronic image products. Images are produced from the best available original document. 


\section{Summary}

This report summarizes Pacific Northwest Laboratory's fiscal year (FY) 1995 progress toward developing and implementing methods to identify and quantify cyanide species in ferrocyanide tank waste. This work was conducted for Westinghouse Hanford Company's (WHC's) Ferrocyanide Safety Program. Currently, there are 18 high-level waste storage tanks at the U.S. Department of Energy's Hanford Site that are on a Ferrocyanide Tank Watchlist because they contain an estimated $1000 \mathrm{~g}-$ moles or more of precipitated ferrocyanide. In the presence of oxidizing material such as sodium nitrate or nitrite, ferrocyanide can be made to react exothermally by heating it to high temperatures or by applying an electrical spark of sufficient energy (Cady 1993). However, fuel, oxidizers, and temperature are all important parameters. .If fuel, oxidizers, or high temperatures (initiators) are not present in sufficient amounts, then a runaway or propagating reaction cannot occur.

To bound the safety concern, methods are needed to definitively measure and quantitate ferrocyanide concentration present within the actual waste. The target analyte concentration for cyanide in waste is approximately 0.1 to $15 \mathrm{wt} \%$ (as cyanide) in the original undiluted sample. After dissolution of the original sample and appropriate dilutions, the concentration range of interest in the analytical solutions can vary between 0.001 to $0.1 \mathrm{wt} \%$ (as cyanide).

In FY 1992, 1993, and 1994, two solution (wet) methods were developed based on Fourier transform infrared (FTIR) spectroscopy and ion chromatography (IC); these methods were chosen for further development activities. The results of these activities are described below:

1. Dissolution Methods for Ferrocyanide Materials. Ferrocyanide flowsheet materials must be dissolved to obtain accurate quantitative analysis of the cyanide species within the waste. The merits of several methods of dissolution are discussed in this report, as well as the logic for choosing a solvent based on ethylenediaminetetraacetic acid (EDTA) and ethylenediamine (en) in water.

2. Influence of Chemical Additives on Cyanide Species Analysis. Many inorganic and organic chemicals are known or suspected to be present within the ferrocyanide tank waste matrix; these chemicals could interfere with cyanide analysis. To determine the extent of interference, we prepared test solutions containing low concentrations of the analytes of interest $\left[\mathrm{CN}^{-}, \mathrm{Fe}(\mathrm{CN})_{6}^{4-}\right.$, and $\mathrm{Fe}(\mathrm{CN})_{6}^{3-}$ ] were prepared with conservatively high concentrations of the potential interfering additive. These solution concentrations were chosen to represent the most difficult for analysis of each analyte. If interference was not observed for these solutions, then any analyte solution encountered from actual samples containing these components would not be expected to show interference. The aging effect on cyanide species (during approximately a 2-month period) of the solutions containing chemical additives was monitored to assess shelf-life of analyte solutions before analysis.

For free cyanide and ferrocyanide analytes, interference was not observed from the additives tested. Nitrite was the only inorganic additive observed to interfere with the detection of the ferricyanide analyte by the quantitative conversion of the ferricyanide complex to ferrocyanide. Several organic additives also reacted with ferricyanide to produce the ferrocyanide complex. In all cases, the conversion was quantitative, and the total cyanide concentration was accurately determined. 
We found that for IC there is quantitative measurement of the ferricyanide and ferrocyanide with added organic interferents. Quantitative measurements for these cyanide complexes also were found with added inorganic interferents, with the exception of nitrate and nitrite ions. This problem is not associated with the ability of the IC system to separate the nitrate or nitrite ions from the ferricyanide and ferrocyanide species, but is due to the co-absorbance of these interfering ions with the cyanide complexes of interest.

3. Test Procedure to Determine Cyanide Species from Ferrocyanide Flowsheet Materials. A draft procedure is presented for determining major cyanide species $\left[\mathrm{CN}^{-}, \mathrm{Fe}(\mathrm{CN})_{6}^{4-}\right.$, and $\left.\mathrm{Fe}(\mathrm{CN})_{6}^{3-}\right]$ expected in samples from the Hanford ferrocyanide waste tanks. We have selected these analytes because they consist of most of the reasonable forms of cyanide possible resulting from the initial addition of ferrocyanide to the 18 waste tanks. The methods are based on FTIR and IC. The overall detection limits for the relevant cyanide-containing species in the original undiluted waste are on the order of $0.1 \mathrm{wt} \%$ (as cyanide) for each method.

4. Methods for Analyzing Flowsheet Materials. Ferrocyanide flowsheet materials including various In-Farm and U-Plant simulated wastes, as well as sodium nickel ferrocyanide standard materials (WHC-3 and FECN-36), were analyzed by different methods. Cyanide analyses were performed by FTIR and IC methods, and by total cyanide analysis (distillation method). The analytical results are presented and compared by method. Excellent agreement was achieved for each method for all simulated waste and standard materials.

5. Influence of $\mathrm{pH}$ on Nitrite Reactivity with $\mathrm{Fe}(\mathrm{CN})_{6}^{3-}$. The reactivity of nitrite with ferricyanide to form ferrocyanide under analytical measurement conditions is of interest to this program, because the speciation and quantification of each of the cyanide complexes in solution depends on the relative stability of these complexes during analysis. Earlier in this task we demonstrated that nitrite will reduce ferricyanide to form ferrocyanide quantitatively. The $\mathrm{pH}$ dependence of the reaction of ferricyanide with nitrite is of interest because, depending on conditions, this reaction may occur within the radioactive waste tank or during the required laboratory treatment steps prior to analysis. In solutions with $\mathrm{pH} 12$, the conversion of ferricyanide to ferrocyanide was complete and quantitative. At lower $\mathrm{pH}$ levels $(4$ to 10$)$ the conversion of ferricyanide to ferrocyanide was reduced. At these lower $\mathrm{pH}$ values, the formation of nitroprusside $\left[\mathrm{Fe}(\mathrm{CN})_{5} \mathrm{NO}^{2-}\right]$ was observed. In all cases, a qualitative measurement of the cyanide species in solution was maintained.

6. Location of FTIR Analytical System into Radiation Zone. FTIR equipment was transferred and installed within a radiologically controlled laboratory. The detector and analytical cell used for the analysis of solution samples was mounted remotely from the main optical bench in order to allow placement of the detector into a radiologically controlled fume hood. This attachment was made through a light guide from the main optical bench into the remote sample compartment. The method detection limit (MDL) was measured for the system with the sample cell directly attached within the main optical bench (normal setup), and with the remote detector attached. The MDL for the direct attachment was $5.9 \mathrm{ppm}$ (wt \% cyanide) and $7.4 \mathrm{ppm}$ (wt\% cyanide) for the remote attachment. This small difference between MDL values for the two attachment modes indicates that there is effectively no loss in quantitative limits by remote detector application. 
7. Solid Analysis of Simulated Ferrocyanide Waste by FTIR. Methods for reproducibly measuring solid samples for analytes of interest, with little or no sample preparation, are useful in many aspects of the Ferrocyanide Safety Program. Limited work was performed on quantitative measurement of solid samples using FTIR techniques. Two methods were initially employed, attenuated total reflectance (ATR) and transmission mode using $\mathrm{KBr}$ pellets.

The ATR method showed problems with reproducibility between samples generated from different simulated waste preparations. This lack of reproducibility in the quantitative measurement was determined to be caused by differences in surface characteristics between samples; the ATR method is a surface analytical method and changes in the surface properties of the analyte material cause major changes in the detected signal.

The transmission technique was demonstrated successfully for quantitative measurement of simulant samples. The transmission method uses light that passes through a homogenized sample to measure the quantity of the analyte species within the sample. Because the infrared light penetrates the entire sample, the measurement is a bulk property of the sample. Differences in surface properties of different samples have little or no effect on the transmission measurements.

In FY 1995, we continued the investigation by measuring the influence of chemical additives on the IC to enable the quantitative measurement of radiocesium in the presence of nitrate and nitrite ions. We also developed a method to reduce the radiocesium content of the ferrocyanide waste to enable the reduction of personnel exposure during the analysis of actual waste samples. This ion exchange method was demonstrated on ferrocyanide waste simulants as well as actual ferrocyanide waste. Lastly, a procedure for the determination of cyanide species using IC and FTIR was prepared. The results of these activities are described below:

1. Influence of Chemical Additives on Cyanide Species Analysis. Simulant testing using IC methods has been completed. Quantitative measurement for ferrocyanide and ferricyanide using IC techniques has been extended to include the inorganic interferant ions, nitrate, and nitrite.

2. Reduction of ${ }^{137} \mathrm{Cs}$ Content in Actual Waste Samples to Address ALARA Concerns. Because of the high ${ }^{137} \mathrm{Cs}$ content in actual ferrocyanide tank samples, personnel exposure needed to be reduced to as low a reasonably achievable (ALARA). To address this need we adapted existing methods for cesium ion removal currently performed on flammable gas tank waste (Campbell et al. 1994) to the ferrocyanide tank waste. This method has been successfully demonstrated for the removal of significant levels of radioactivity from tank samples to allow bench-top handling. This will benefit the program in terms of reduced personnel exposure as well as time savings during actual sample manipulation and measurement.

3. Demonstration of FTIR and IC Analytical Methods on Actual Ferrocyanide Tank Waste. Actual ferrocyanide waste samples from tanks $241-\mathrm{C}-109$ and 241-C-112 were analyzed for cyanide content by FTIR, IC, and total cyanide methods. The radiocesium was removed by ion exchange prior to removing samples from the hot cells for FTIR and IC analysis. The total cyanide content was measured prior to and after ion exchange; the FTIR and IC methods were performed after ion exchange only. Excellent agreement was observed between these methods of analysis for actual waste samples. 



\section{Abbreviations}

AA atomic absorption

ALARA as low as reasonably achievable

ATR attenuated total reflectance

DIW deionized water

DOE U.S. Department of Energy

DXRD dynamic $x$-ray diffraction

EDTA ethylenediaminetetraacetic acid

EIS environmental impact statement

en ethylenediamine

FTIR Fourier transform infrared (spectroscopy)

FY fiscal year

HEDTA hydroxyethyl-ethylenediaminetriacetic acid

HPLC high-performance liquid chromatograph

IC ion chromatography

IDA iminodiacetic acid

IR infrared

IX ion exchange

MDL method detection limit

NPH normal paraffin hydrocarbon

NTA nitrilotriacetic acid

PNL Pacific Northwest Laboratory

SST single-shell tank 
USQ

unreviewed safety question

WHC

Westinghouse Hanford Company 


\section{Contents}

Summary $\ldots \ldots \ldots \ldots \ldots \ldots \ldots \ldots \ldots \ldots \ldots \ldots \ldots \ldots \ldots \ldots$ iii

Abbreviations $\ldots \ldots \ldots \ldots \ldots \ldots \ldots \ldots \ldots \ldots \ldots \ldots \ldots \ldots \ldots \ldots$

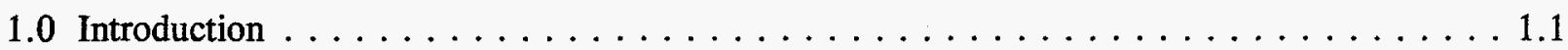

2.0 Influence of Chemical Additives on Cyanide Species Analysis Using Ion Chromatography . . 2.1

2.1 Influence of Inorganic Additives on Ferrocyanide $\left[\mathrm{Fe}(\mathrm{CN})_{6}^{-4}\right]$ and Ferricyanide

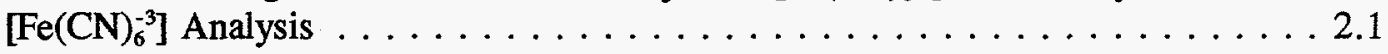

2.2 Influence of Nitrate and Nitrite On Ferrocyanide $\left[\mathrm{Fe}(\mathrm{CN})_{6}^{-4}\right]$ and Ferricyanide $\left[\mathrm{Fe}(\mathrm{CN})_{6}^{-3}\right]$ Analyses by Ion Chromatography . . . . . . . . . 2.2

3.0 Reduction of Cesium From Simulated Ferrocyanide Waste Using Ion Exchange $\ldots \ldots$. . . 3.1

3.1 Reduction of Cesium from Simulated In-Farm Ferrocyanide Waste $\ldots \ldots \ldots . . .1$

3.2 Reduction of Cesium from Simulated U-Plant Ferrocyanide Waste $\ldots \ldots \ldots .2$

4.0 Analysis of Actual Ferrocyanide Tank Waste $\ldots \ldots \ldots \ldots \ldots \ldots \ldots \ldots \ldots \ldots$

4.1 Reduction of Cesium from Actual Ferrocyanide Waste $\ldots \ldots \ldots \ldots \ldots \ldots$

4.2 Actual Ferrocyanide Waste Analysis $\ldots \ldots \ldots \ldots \ldots \ldots \ldots \ldots \ldots$

4.3 Comparison of Analyses of Tank 241-C-112 Ferrocyanide Waste Sample by Different Analytical Methods . . . . . . . . . . . . . . 4.5

5.0 Test Procedure to Determine Cyanide Species in Ferrocyanide Tank Waste Materials . . . . 5.1

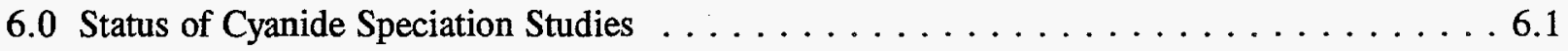

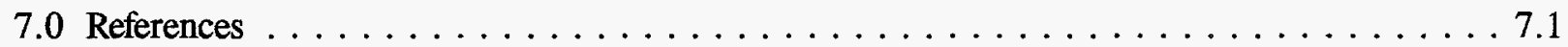




\section{Figures}

Figure 2.1 IC Chromatogram Showing Separation of Ferricyanide and Ferrocyanide Ions $\ldots \ldots \quad 2.4$

Figure 2.2 Concentration of Total Cyanide Species (Ferricyanide and Ferrocyanide) in Solution Originally Containing Ferricyanide $0.025 \mathrm{wt} \%$ (as cyanide) and Inorganic Additive. 2.5

Figure 2.3 Concentration of Total Cyanide Species (Ferrocyanide) in Solution Originally Containing Ferrocyanide 0.025 wt\% (as cyanide) and Inorganic Additive.

Figure 2.4 Concentration of Ferrocyanide in Solutions Containing Various Amounts of Nitrate . . . . . . . . . . . . . . . . . . . .

Figure 2.5 Concentration of Ferrocyanide in Solutions Containing Various Amounts of Nitrite

Figure 2.6 Concentration of Ferricyanide in Solutions Containing Various Amounts of Nitrate

Figure 2.7 Concentration of Ferricyanide in Solutions Containing Various Amounts of Nitrite

Figure 4.1 Gamma Scan for a Selected Actual Ferrocyanide Waste Sample (Tank 241-C-109, Core 49, Composite 1B)

Figure 4.2 FTIR Spectrum of Actual Ferrocyanide Waste Sample from Tank 241-C-112, Core 36, Composite 2C 


\section{Tables}

Table 2.1 List of Tested Inorganic and Organic Additives.

2.2

Table 3.1 Ferrocyanide Recovery and Cesium Removal From In-Farm 2

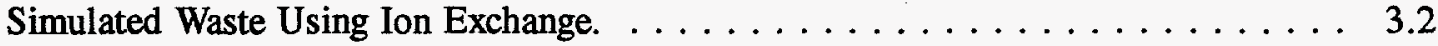

Table 3.2 Ferrocyanide Recovery and Cesium Removal From U-Plant

Simulated Waste Using Ion Exchange.

Table 4.1 $\quad{ }^{137}$ Cs Concentrations and Decontamination Factors For Cesium Removal From Various Actual Tank Waste Samples.

Table 4.2 ${ }^{137} \mathrm{Cs}$ Concentrations and Decontamination Factors For Cesium Removal From Various Actual Tank Waste Samples.

Table 4.3 Comparison of Cyanide Concentrations Measured for Various Analytical Techniques. 


\subsection{Introduction}

The research performed for this project is part of an effort that started in the mid-1980s to characterize the materials stored in the single-shell waste storage tanks (SSTs) at the U.S. Department of Energy (DOE) Hanford Site. Various radioactive wastes from defense operations have accumulated at the Hanford Site in underground waste tanks since the early 1940s.

During the $1950 \mathrm{~s}$, additional tank storage space was required to support the defense mission. Hanford Site scientists developed two procedures to obtain this additional storage volume within a short time period without constructing additional storage tanks. One procedure involved the use of evaporators to concentrate the waste by removing water. The second procedure involved developing precipitation processes for scavenging radiocesium and other soluble radionuclides from tank waste liquids. The scavenging processes used sodium and potassium ferrocyanide and nickel sulfate to precipitate radioactive cesium from solutions containing nitrates and nitrites. Radioactive strontium and cobalt were scavenged from some of the solutions using calcium or strontium nitrate and sodium sulfide, respectively. After allowing the radioactive precipitates to settle, the decontaminated solutions were pumped to disposal cribs, thereby providing additional tank storage volume. Later, some of the tanks were found to be leaking; pumpable liquids were removed from these tanks, leaving behind a wet solid (sludge) residue containing the ferrocyanide precipitates (Burger et al. 1991). In implementing this process, approximately 140 metric tons of ferrocyanide, [calculated as $\mathrm{Fe}(\mathrm{CN})_{6}^{4}$ ], were added to waste that was later routed to 18 large $(750,000$ to $1,000,000$ gallon) underground SSTs.

The explosive nature of ferrocyanides in the presence of oxidizers has been known for decades, but the conditions under which impure mixtures containing nitrates and nitrites can undergo propagating reactions had not been thoroughly studied. At the Hanford Site, the potential reactivity of mixtures of ferrocyanides, nitrates, and nitrites was first recognized when the radiocesium scavenging process using ferrocyanide was investigated for application to radioactive wastes produced by the next generation processing technology. The investigation found that cesium zinc ferrocyanide and nitrate exploded when heated (Hepworth et al. 1957). In the laboratory, mixtures of ferrocyanide and oxidizing materials, such as nitrates and nitrites, have been shown to undergo energetic reactions when heated to high temperatures (above $250^{\circ} \mathrm{C}$ ) or exposed to an electrical spark of sufficient energy to heat the mixture (Cady 1993). Because the scavenging process precipitated ferrocyanide from solutions containing nitrate and nitrite, an intimate mixture of ferrocyanides and nitrates and/or nitrites is likely to exist in some regions of the ferrocyanide tanks.

Efforts have been underway since the mid-1980s to evaluate the potential for ferrocyanide reactions in Hanford Site SSTs (Burger 1984; Burger and Scheele 1988; Meacham et al. 1995). The 1987 Environmental Impact Statement (EIS), Final Environmental Impact Statement, Disposal of Hanford Defense High-Level Transuranic and Tank Waste, Hanford Site, Richland, Washington (DOE 1987), included an environmental impact analysis of potential explosions involving ferrocyanide-nitrate mixtures. The EIS postulated that an explosion could occur during mechanical retrieval of saltcake or sludge from a ferrocyanide waste tank. The EIS concluded that this worst-case accident could create enough energy to release radioactive material to the atmosphere through ventilation openings, exposing persons offsite to a short-term radiation dose of approximately 200 mrem. A General Accounting Office study (Peach 1990) postulated a greater worst-case accident, with independently calculated doses of one to two orders of magnitude greater than postulated in the DOE EIS. Uncertainties regarding the safety envelope of the Hanford Site ferrocyanide waste tanks led to the declaration of the ferrocyanide unreviewed safety question (USQ) in October 1990. 
Despite the fact that the measured temperatures in these tanks continue to drop and the highest temperature currently recorded is $53.3^{\circ} \mathrm{C}$ (Hanlon 1995), there has been speculation as to the possibility of "hot spots" forming in the tanks from radiolytic heating. In order to address these concerns, a number of studies have been conducted by Westinghouse Hanford Company (WHC), Pacific Northwest Laboratory (PNL), ${ }^{\left({ }^{2}\right)}$ and others in an effort to identify the reactions that occur, and to quantify the magnitude of the energy released during reactions (Burger 1984; Burger and Scheele 1988, 1990; Scheele et al. 1991, 1992; Scheele and Cady 1989; Hallen et al. 1991; Epstein et al. 1994; Dickinson et al. 1993).

The Westinghouse Hanford Company (WHC) Ferrocyanide Safety Program was implemented in September 1990 to address this priority one safety issue. This program is composed of four principal components. The first component, tank monitoring, involves developing, deploying, and maintaining instrumentation for continuous monitoring of the tank contents. The second program component, modeling and analyzing existing tank data, allows predictive calculations of, for example, the existence of hot spots within the waste or concentrations of gases within the tank dome space. Ferrocyanide waste characterization using waste simulants and actual tank samples is the third program component. The third activity focuses on the chemical analysis of gas space, surface samples, and core samples from the ferrocyanide tanks. The fourth program component is research and development. This activity's objective is to understand the potentially hazardous reactions of precipitated ferrocyanides and their aging products within SST ferrocyanide waste.

This report focuses on activities for the third component of the Ferrocyanide Safety Program, characterization of ferrocyanide waste. The contents of this report are arranged in order of the requirements to analyze ferrocyanide species. Following the introduction, Section 2.0 discusses the influences of the chemical additives nitrate and nitrite on cyanide species analysis by ion chromatography (IC). Section 3.0 discusses the reduction of cesium from simulated waste by ion exchange methods. Section 4.0 presents the results of analyses of actual ferrocyanide tank waste. Section 5.0 presents experimental methods and the draft test procedure developed by this task for analyzing cyanide complexes. Section 6.0 summarizes the status of the cyanide species studies within this task. Section 7.0 contains a reference list.

(a) Operated for the U.S. Department of Energy by Battelle Memorial Institute under Contract DE-AC06-76RLO 1830. 


\subsection{Influence of Chemical Additives on Cyanide Species Analysis Using Ion Chromatography}

Dissolved ferrocyanide waste and simulated waste contain an array of chemical species that may interfere with the analytical solution methods used to quantify cyanide complexes. To assess the impact of the suspected interferant species, we have systematically measured cyanide complexes of interest with and without the additives (Bryan et al. 1994). Table 2.1 lists the chemical species tested to date. The species concentrations were chosen based on ferrocyanide and SST simulated waste flowsheets (U-Plant and In-Farm). We have demonstrated that the species in Table 2.1 do not interfere with the analyses of ferrocyanide, ferricyanide, or free cyanide when using the IC of Fourier transform infrared (FTIR) spectroscopy methods. The exception to this is the analysis of ferrocyanide and ferricyanide by ion chromatography when high concentrations of nitrate or nitrite are present.

Ferrocyanide waste simulants containing high concentrations of nitrate and nitrite were reported to give low percent recovery for ferrocyanide $\left[\mathrm{Fe}(\mathrm{CN})_{6}^{-4}\right]$ and ferricyanide $\left[\mathrm{Fe}(\mathrm{CN})_{6}^{-3}\right]$ ions by the IC method (Bryan et al. 1994). The source of the low analyte recovery has been identified and corrected.

Figure 2.1 shows an IC chromatogram for the separation of ferricyanide $\left[\mathrm{Fe}(\mathrm{CN})_{6}^{3}-\right]$ and ferrocyanide $\left[\mathrm{Fe}(\mathrm{CN})_{6}^{4}-\right]$, each at the 50 -ppm concentration level. This chromatogram demonstrates that these ions can be spatially separated by retention time as well as resolved by their characteristic absorbencies in the UV-vis spectrum. The solvent used in this experiment is the complexant pretreatment solution developed by Bryan et al. (1993). This example chromatogram shows the potential for using this method to speciate the various complexes of cyanide at low concentrations.

The lowest detection limit is sought in order to allow for dilution of tank waste samples during the dissolution process prior to analysis. The dilution factor for a tank waste sample is dependent in part on the concentration of the cyanide species present, but also on the activity of the radionuclides within the sample. By achieving the best detection limit possible, we are able to demonstrate two important goals: 1) a best lower-bound quantitation limit, and 2) attention to as low as reasonably achievable (ALARA) concerns to minimize personnel exposure. Method detection limits have been described in detail for these methods in an earlier report (Bryan et al. 1994).

\subsection{Influence of Inorganic Additives on Ferrocyanide $\left[\mathrm{Fe}(\mathrm{CN})_{6}^{4-}\right]$ and Ferricyanide $\left[\mathrm{Fe}(\mathrm{CN})_{6}^{3-}\right]$ Analysis}

Ferrocyanide simulants containing potential inorganic interferents have been prepared and analyzed by IC and FTIR. Solutions containing $250 \mathrm{ppm}\left(0.025 \mathrm{wt} \%\right.$ as cyanide) ferrocyanide $\left[\mathrm{Fe}(\mathrm{CN})_{6}^{4-}\right]$ and ferricyanide $\left[\mathrm{Fe}(\mathrm{CN})_{6}^{3-}\right]$, with various amounts of inorganic interferant concentrations were analyzed previously using the high-performance liquid chromatograph (HPLC) system with the photo-diode array detector system and the FTIR system equipped with the ATR solution cell (Bryan et al. 1993, 1994). The results of this test show that the measured concentration of the cyanide in each solution is essentially the concentration of cyanide complex added initially to each solution, with the exception of the IC method with nitrite and nitrate added to the analytical solution. For the analysis of both the ferricyanide and ferrocyanide by IC, the solutions containing nitrite and nitrate show low analyzed cyanide complex (see Figures 2.2 and 2.3). 
Table 2.1 List of Tested Inorganic and Organic Additives

\begin{tabular}{lll}
$\begin{array}{l}\text { Inorganic } \\
\text { Additives }\end{array}$ & & \multicolumn{1}{c}{ Organic Additives } \\
\cline { 3 - 3 } $\mathrm{Na}_{2} \mathrm{SO}_{4}$ & & Sodium citrate \\
$\mathrm{Na}_{2} \mathrm{CO}_{3}$ & & Sodium acetate \\
$\mathrm{Na}_{3} \mathrm{PO}_{4}$ & & Sodium formate \\
$\mathrm{NaCl}$ & & Normal paraffin hydrocarbon (NPH) (saturated) \\
$\mathrm{NaNO}_{2}$ & & Sodium oxalate \\
$\mathrm{Na}_{2} \mathrm{CrO}_{4}$ & Hydroxyethyl-ethylenediaminetriacetic acid (HEDTA) \\
$\mathrm{NaF}$ & Tributylphosphate (TBP) (saturated) \\
$\mathrm{NaNO}_{3}$ & Glycerin \\
& Ethylenediaminetetraacetic acid (EDTA) \\
& Sodium glycolate \\
& Iminodiacetic acid (IDA) \\
& Glycine \\
& Nitrilotriacetic acid (NTA) \\
& N-butanol \\
& Ethylenediamine (en)
\end{tabular}

\subsection{Influence of Nitrate and Nitrite On Ferrocyanide and Ferricyanide Analyses by Ion Chromatography}

Ferrocyanide tank waste simulants containing high concentrations of nitrate and nitrite were reported to give low percent recovery for ferrocyanide $\left[\mathrm{Fe}(\mathrm{CN})_{6}^{-4}\right]$ and ferricyanide $\left[\mathrm{Fe}(\mathrm{CN})_{6}^{-3}\right]$ ions by the IC method (Bryan et al. 1994). The source of the low analyte recovery has been identified and corrected.

The source of the error during the analysis of ferrocyanide or ferricyanide in earlier work is attributed to overloading the IC column with excess nitrate or nitrite. This problem has been eliminated by simple dilution of the sample matrix to limit the concentration of nitrate and nitrite ions to approximately $1500 \mathrm{ppm}$ or less. Figures 2.4 and 2.5 show IC data for the analysis of the ferrocyanide ion, $\mathrm{Fe}(\mathrm{CN})_{6}^{4-}$, in the presence of varying amounts of nitrate and nitrite. These data show that the analysis of ferrocyanide by IC is quantitative in the presence of concentrations of nitrite and nitrate when the concentrations of the nitrite and nitrate are kept at $1500 \mathrm{ppm}$ or less.

A similar trend is seen for the analysis of ferricyanide ion, $\mathrm{Fe}(\mathrm{CN})_{6}^{3-}$, in the presence of nitrate and nitrite. Figures 2.6 and 2.7 provide the data on the IC analysis of ferricyanide in the presence of various amounts of nitrate and nitrite. Ferricyanide can be quantitatively analyzed by IC when the concentration of both nitrate and nitrite is at or below approximately $1000 \mathrm{ppm}$.

On a typical waste sample with an expected nitrate and nitrite concentration of $10 \mathrm{wt} \%$, a dilution factor of 100 will yield the final concentration of the nitrate and nitrite species at $1000 \mathrm{ppm}(0.10$ wt \%). The same dilution factor of 100 on a sample containing $0.1 \mathrm{wt} \%$ (as cyanide) ferrocyanide will 
yield an analyte solution concentration of $10 \mathrm{ppm}$ for ferrocyanide, well within the quantitation range for this species by IC. The quantitative limits of this technique are described in more detail in an earlier report (Bryan et al. 1994). 


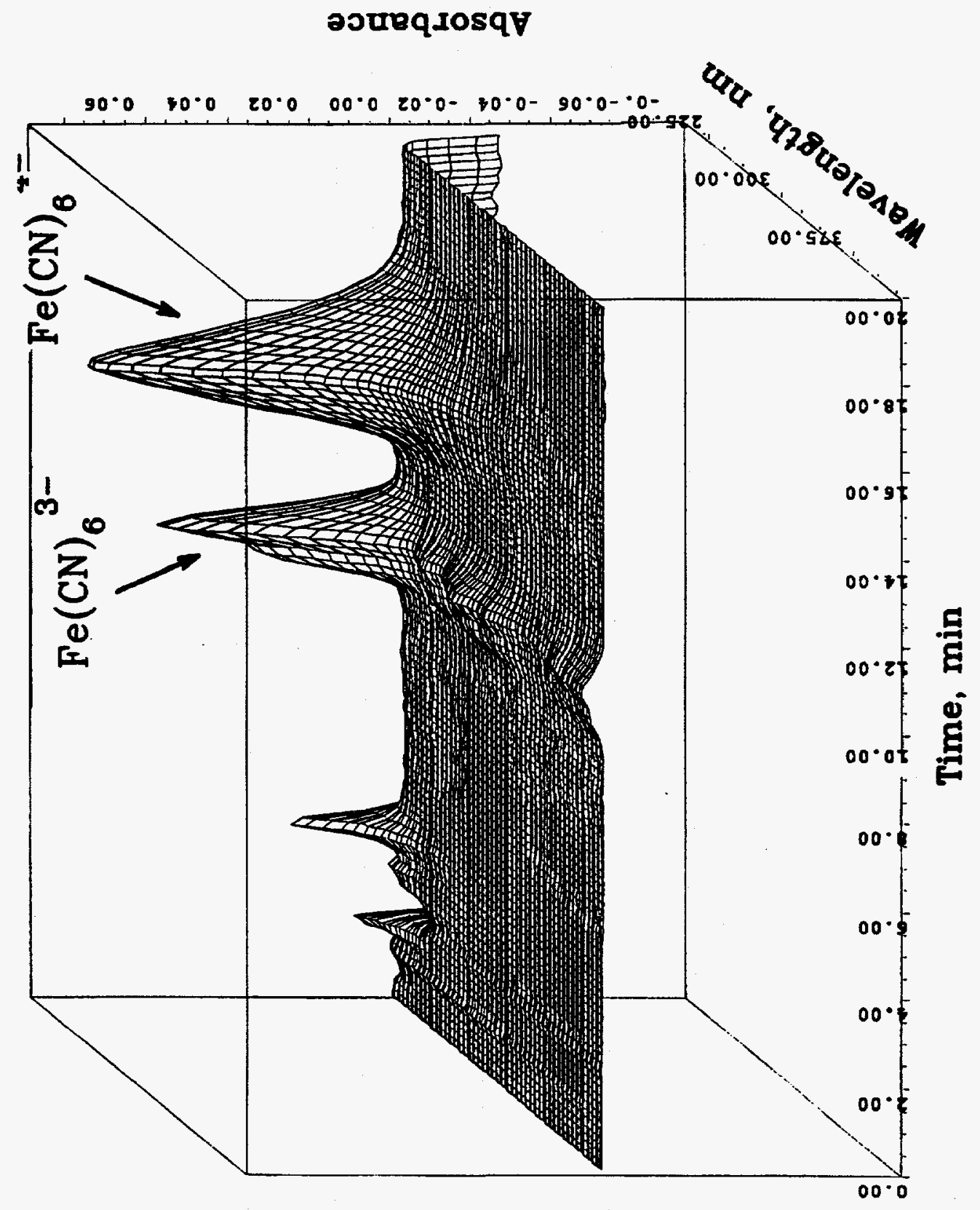

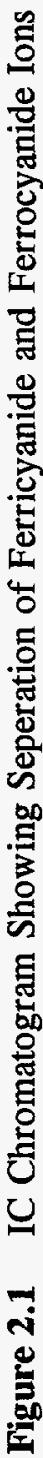




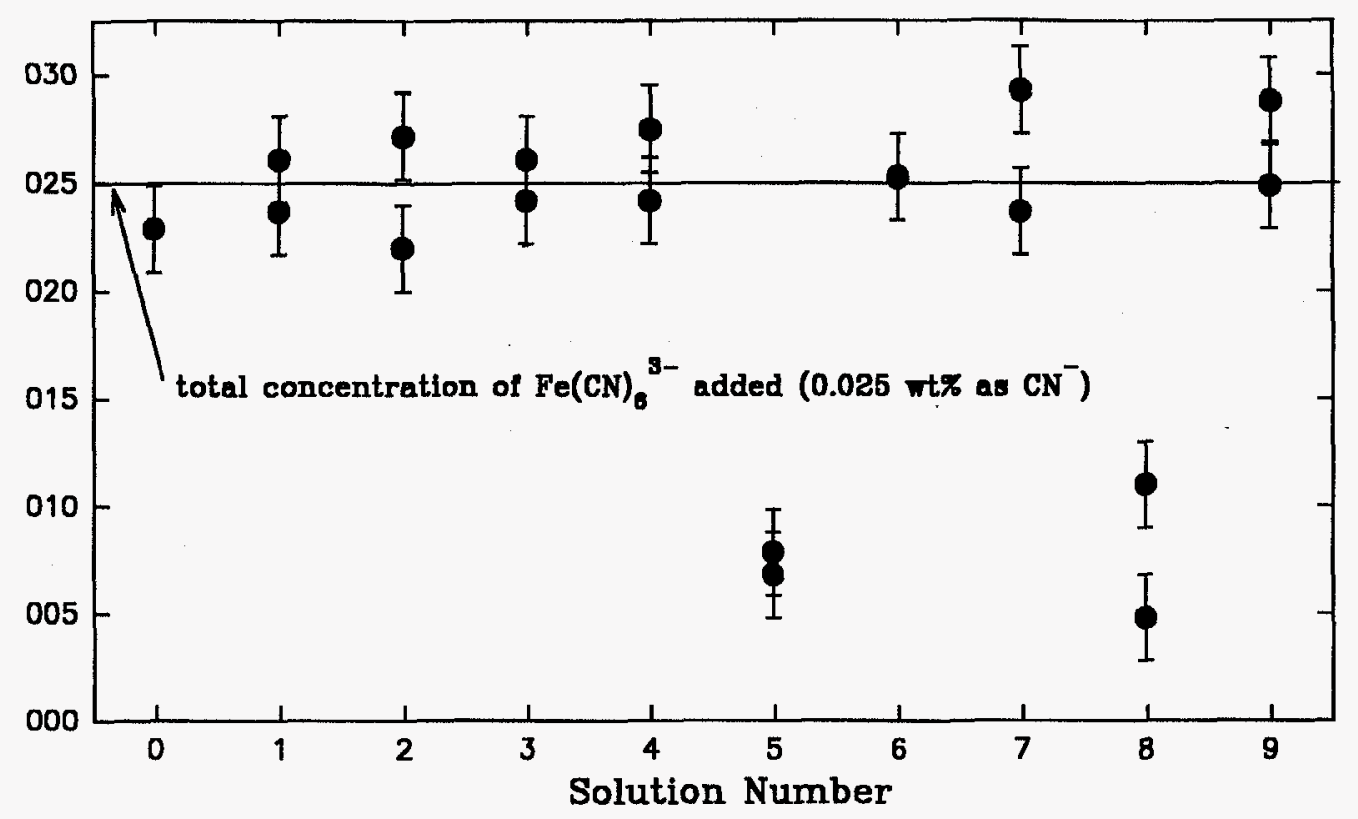

all solutions initially contained $\mathrm{Fe}(\mathrm{CN})_{B}^{3-}\left(0.025 \mathrm{wt \%} \mathrm{as} \mathrm{CN}^{-}\right)$with listed additive
0. $0.025 \mathrm{wtz} \mathrm{Fe}(\mathrm{CN})_{3}^{3-}$ (blank)
4. $5.0 \mathrm{wtz} \mathrm{NaCl}$
7. $0.5 \mathrm{wt} \% \mathrm{NaF}$
1. $0.5 \mathrm{wt} \% \mathrm{Na}_{2} \mathrm{SO}_{4}$
5. $20.0 \mathrm{wt} \% \mathrm{NaNO}_{2}$
B. $15.0 \mathrm{wt} \% \mathrm{NaNO}_{3}$
2. $2.5 \mathrm{wt} \% \mathrm{Na}_{\mathrm{g}} \mathrm{CO}_{3}$
3. $2.7 \mathrm{wt}_{6} \mathrm{Na}_{3} \mathrm{PO}_{4}$
6. $1.5 \mathrm{wt} \% \mathrm{Na}_{2} \mathrm{CrO}_{4}$
9. $2.5 \mathrm{wt \%} \mathrm{NaAlO}_{\mathrm{g}}$

Figure 2.2 Concentration of Total Cyanide Species (Ferricyanide and Ferrocyanide) in Solution Originally Containing Ferricyanide $0.025 \mathrm{wt} \%$ (as cyanide) and Inorganic Additive 


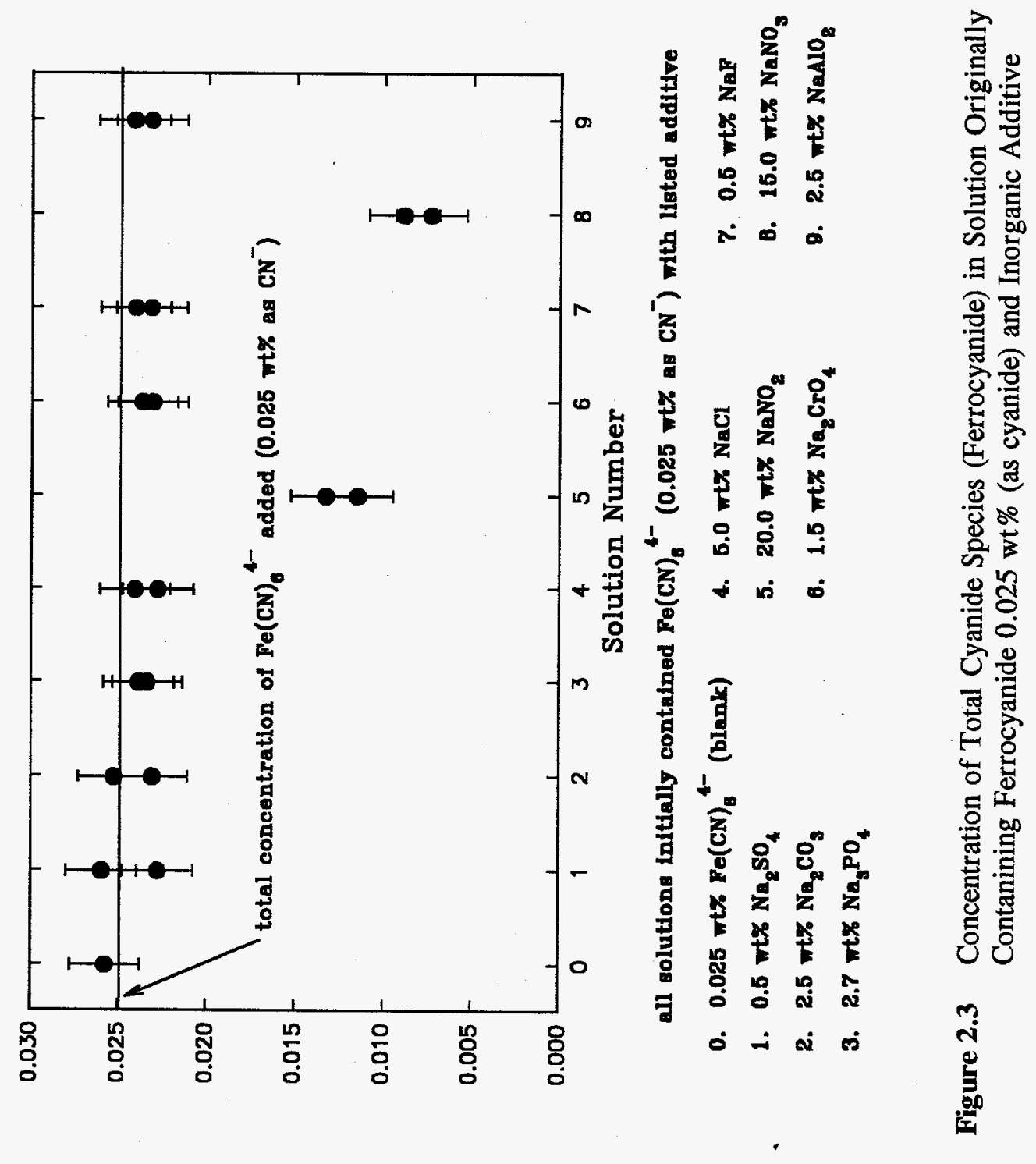




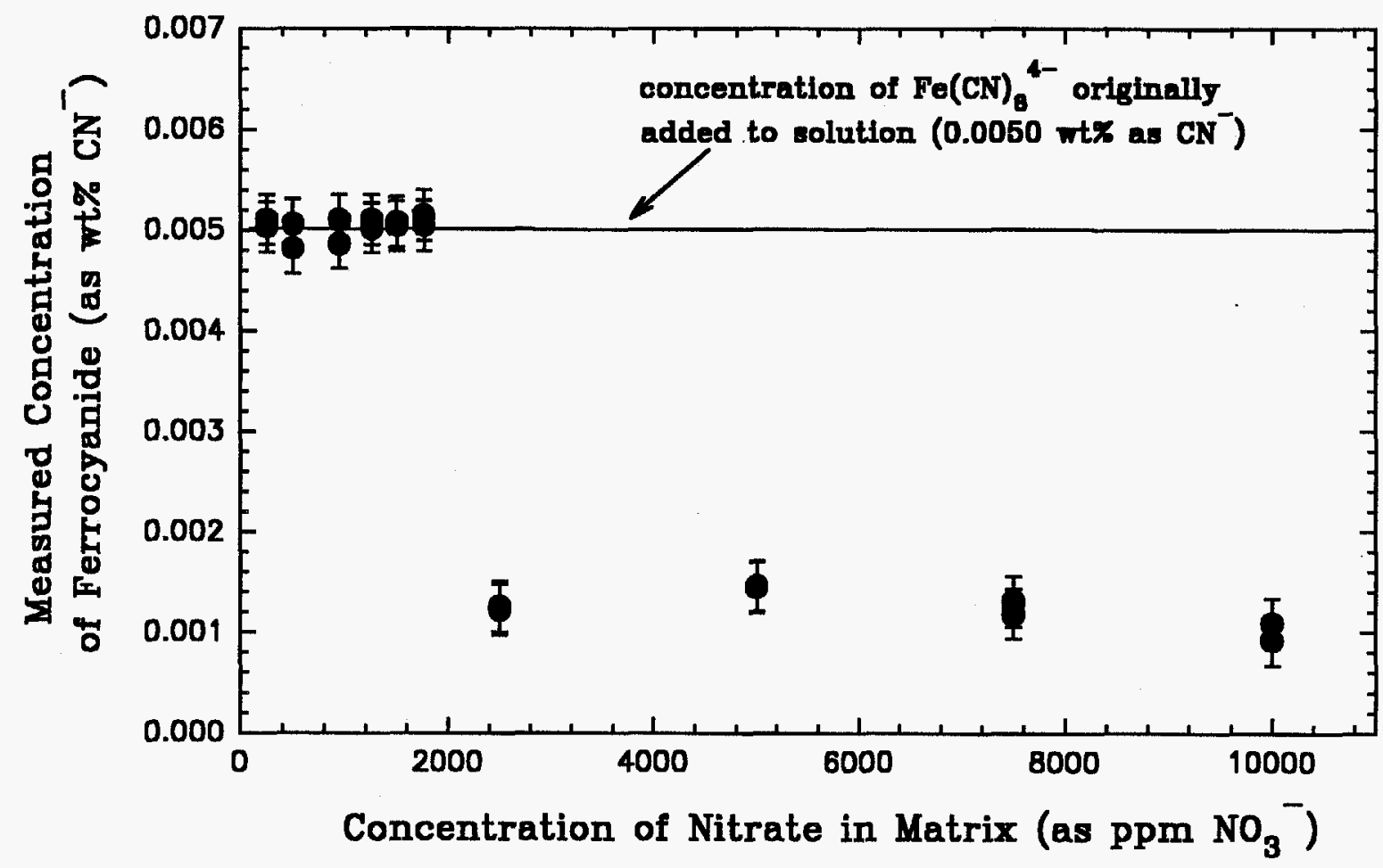

Figure 2.4 Concentration of Ferrocyanide in Solutions Containing Various Amounts of Nitrate 


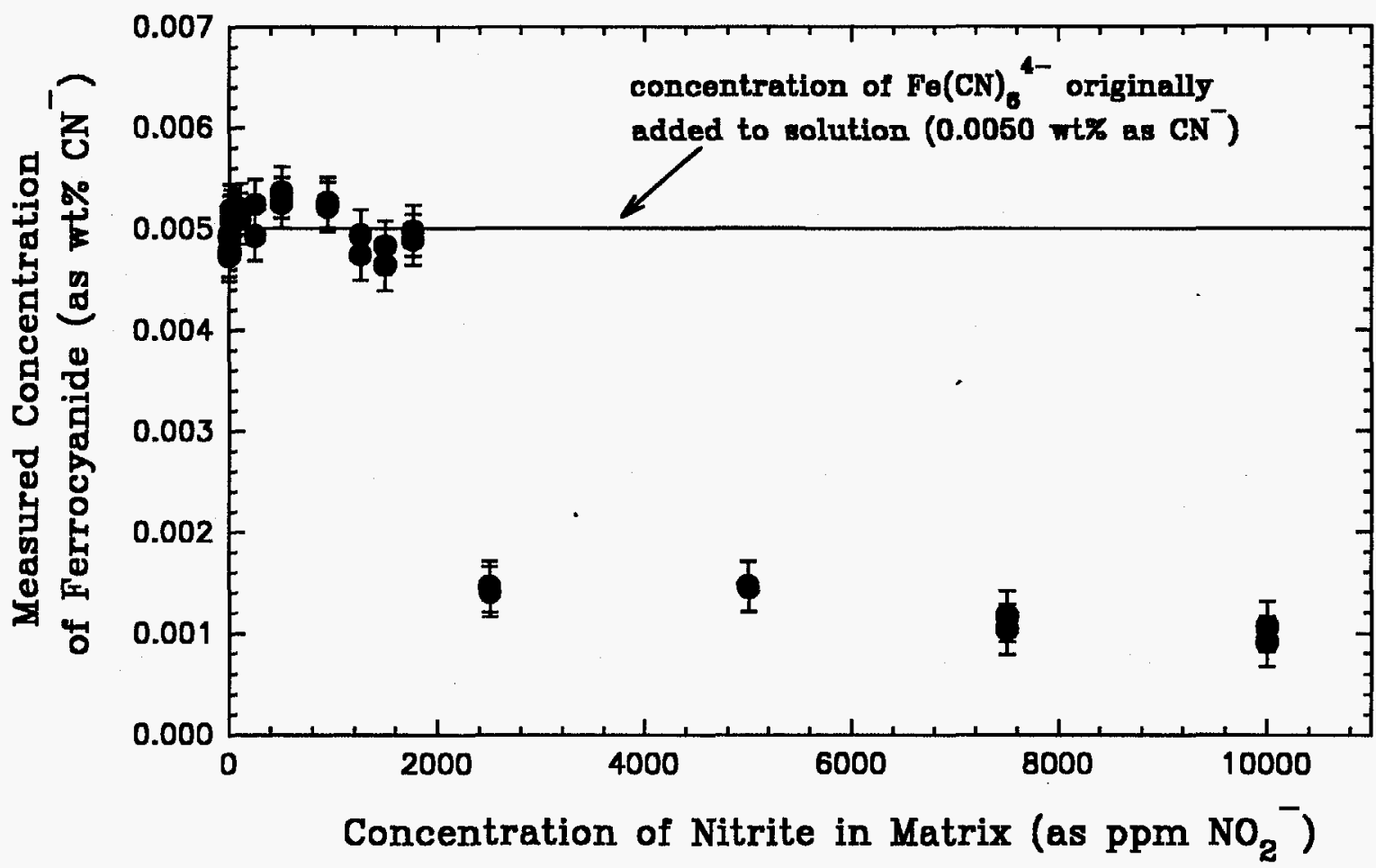

Figure 2.5 Concentration of Ferrocyanide in Solutions Containing Various Amounts of Nitrite 


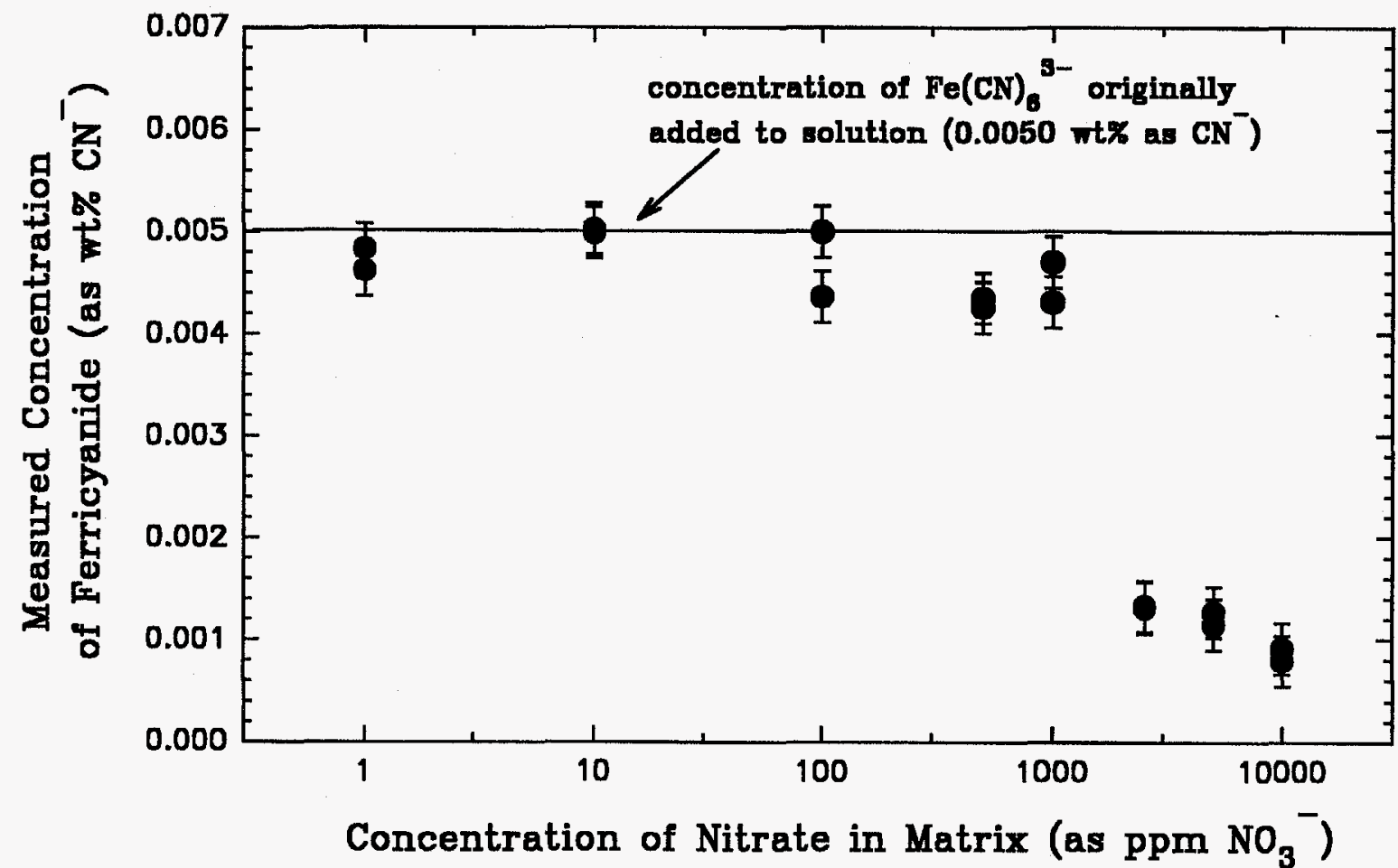

Figure 2.6 Concentration of Ferricyanide in Solutions Containing Various Amounts of Nitrate 
Measured Concentration of Ferricyanide (as wt\% $\mathrm{CN}^{-}$)

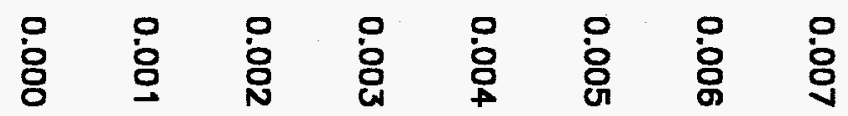

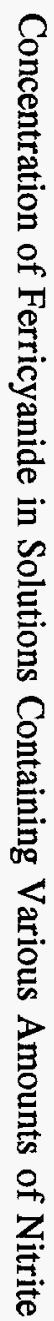

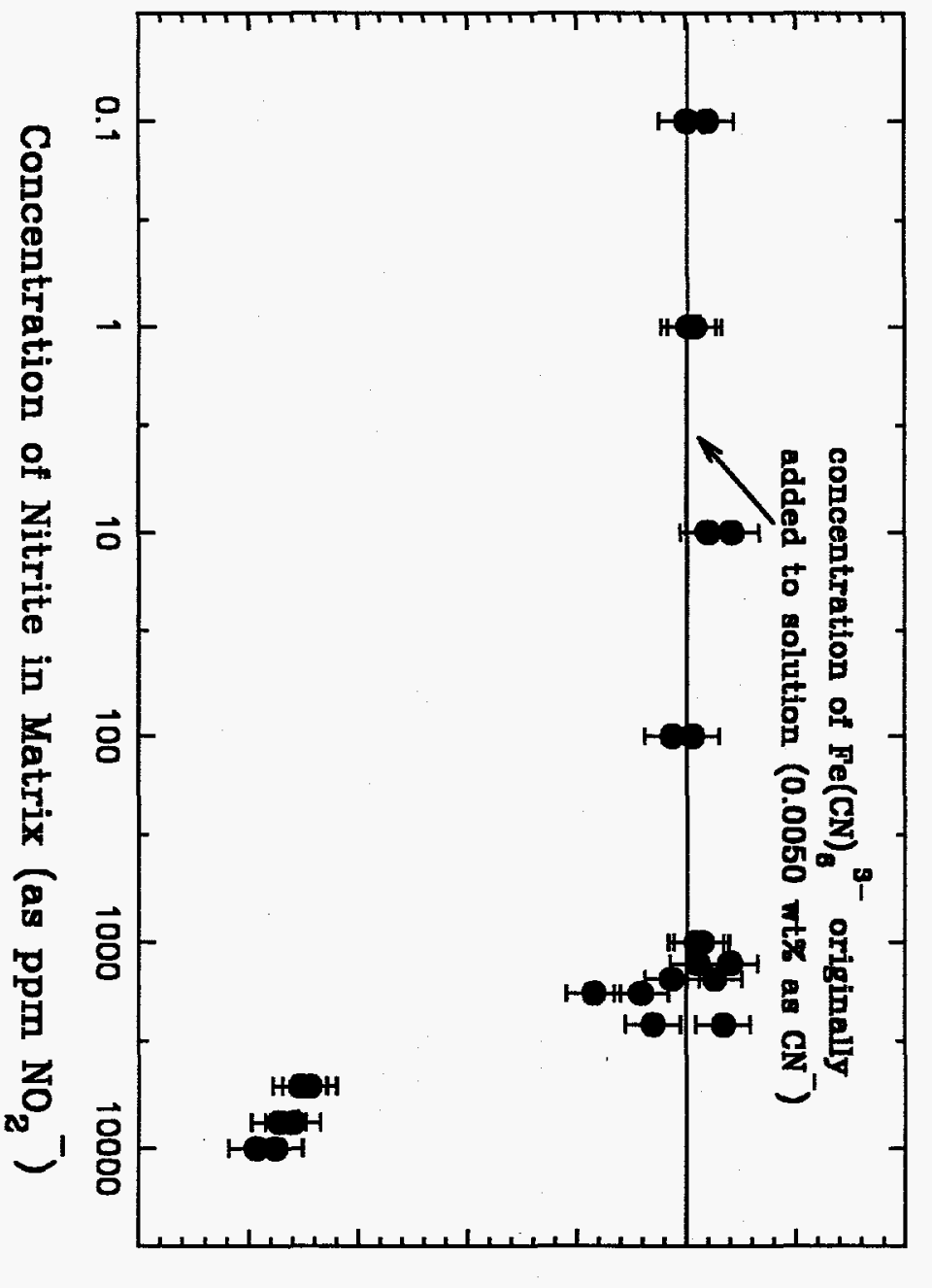




\subsection{Reduction of Cesium From Simulated Ferrocyanide Waste Using Ion Exchange}

Because the ${ }^{137} \mathrm{Cs}$ content in actual ferrocyanide tank samples is high, the personnel exposure needed to be reduced to ALARA. To address this need we adapted existing methods for cesium ion removal currently performed on flammable gas tank waste (Campbell et al. 1994) to the ferrocyanide tank wastes. This method has been successfully demonstrated to remove significant levels of radioactivity from actual Hanford tank wastes other than ferrocyanide waste to allow the samples to be removed from the hot cell environment for bench-top handling. In Sections 3.1 and 3.2, we demonstrate that this ion exchange method can be modified to remove cesium from in-farm and U-plant simulated ferrocyanide wastes. This will benefit the program in terms of reduced personnel exposure as well as time savings during actual sample manipulation and measurement.

\subsection{Reduction of Cesium from Simulated In-Farm Ferrocyanide Waste}

In-Farm 2 flowsheet samples were prepared according to the procedure given by Jeppson and Wong (1993). The samples were centrifuged at $2000 \mathrm{rpm}$ for approximately one hour. Approximately ten grams of simulant was dissolved in $100 \mathrm{~mL}$ of dissolution elixir described in Bryan et al. 1994 (5\% by weight of ethylenediamine (en) and the hydrogen form of EDTA).

The ion exchange resin used was AG 50W-X8, 50-100 mesh (BioRad, Richmond, CA). This resin is a polystyrene-supported sulfonic acid. AG 50W-X8 has an exchange capacity of $4.8 \mathrm{meq} / \mathrm{gm}$ and can be used in the full range of $\mathrm{pH}$. This resin is normally in the hydrogen form, but it was converted to the sodium form by adding excess $2 \mathrm{M}$ sodium hydroxide for 12 hours followed by rinsing with distilled water until the eluent $\mathrm{pH}$ is neutral. Approximately 1-3 grams of the wet resin were packed into small plastic columns and the columns capped.

Before passing the samples through the ion exchange column, three-column volumes of the en/EDTA elixir solution was passed through the column. A 1-3 mL aliquot sample (depending on the column size) of the dissolved simulated waste was pipetted onto the column and allowed to elute using gravity flow. Additional en/EDTA elixir ( 3 fold excess) was added to the column to ensure complete transfer of the sample through the column. All eluent fractions were retained and combined.

The cyanide and cesium content of the In-Farm 2 samples were measured before and after ion exchange removal of cesium. Ferrocyanide was measured by FTIR techniques. Cesium concentrations were measured by atomic absorption (AA). The percent ferrocyanide recovery was calculated based on the moles of ferrocyanide eluted from the ion exchange column per initial moles of ferrocyanide added to column. Likewise, the percent cesium removal was calculated based on the moles of cesium eluted from the column and the total moles of cesium added to the column in the feed.

The percent $\mathrm{Fe}(\mathrm{CN})_{6}^{-4}$ recovery and percent cesium removal from In-Farm 2 flowsheet samples are shown in Table 2. The high level of cesium removal (DF $\geq 25$ ) indicates that a significant fraction of the cesium activity ( $>96 \%$ ) from these samples can be removed prior to sample handling and subsequent analysis. This value indicates that the cesium activity can be reduced by more than an order of magnitude by one pass through the ion exchange column. The high ferrocyanide recovery, greater than $97 \%$ in all cases, indicates that the cesium removal technique will not interfere with the cyanide analysis. 
Table 3.1 Ferrocyanide Recovery and Cesium Removal From In-Farm 2 Simulated Waste Using Ion Exchange

$\begin{array}{cc}\text { Sample } & \text { Ferrocyanide Recovery } \\ 1 & 98.1 \% \\ 2 & 98.3 \% \\ 3 & 97.6 \% \\ 4 & 98.9 \% \\ 5 & 97.8 \% \\ 6 & 97.8 \% \\ 7 & 98.1 \% \\ 8 & 98.0 \% \\ 9 & 97.9 \% \\ 10 & 98.1 \%\end{array}$

(1) $\mathrm{DF}=$ decontamination factor

\subsection{Reduction of Cesium from Simulated U-Plant Ferrocyanide Waste}

U-Plant 2 flowsheet samples were prepared according to the procedure given by Jeppson and Wong (1993). The samples were centrifuged at $2000 \mathrm{rpm}$ for approximately one hour. Approximately ten grams of simulant were dissolved in $100 \mathrm{~mL}$ of dissolution elixir described in Bryan et al. 1994 (5\% by weight of ethylenediamine (en) and the hydrogen form of EDTA).

The ion exchange resin tested for use in cesium ion removal was AG 50W-X8 (BioRad, Richmond, CA). Two mesh sizes were tested, 20-50 mesh and 100-200 mesh; the smaller mesh size is thought to give a better separation because of its higher effective surface area and longer residence time of the solution on the column. This resin is a polystyrene-supported sulfonic acid, has an exchange capacity of $4.8 \mathrm{meq} / \mathrm{gm}$, and can be used in the full range of $\mathrm{pH}$. This resin is normally in the hydrogen form but was converted to the sodium form by adding excess $2 \mathrm{M}$ sodium hydroxide for 12 hours followed by rinsing with distilled water until the eluent $\mathrm{pH}$ was neutral. Approximately 1-3 grams of the wet resin were packed into small plastic columns and the columns capped.

Before passing the samples through the ion exchange column, three-column volumes of the en/EDTA elixir solution was passed through the column. A 1-3 mL aliquot sample (depending on the column size) of the dissolved simulated waste was pipetted onto the column and allowed to elute using gravity flow. Additional en/EDTA elixir ( 3 fold excess) was added to the column to ensure complete transfer of sample through the column. All eluent fractions were retained and combined.

The cyanide and cesium content of the U-Plant 2 flowsheet samples were measured before and after ion exchange removal of cesium. Ferrocyanide was measured by FTIR techniques. Cesium concentrations were measured by AA. The percent ferrocyanide recovery was calculated based on the moles of ferrocyanide eluted from the ion exchange column per initial moles of ferrocyanide added to column. Likewise, the percent cesium removal was calculated based on the moles of cesium eluted from the column and the total moles of cesium added to the column in the feed. 
The percent $\mathrm{Fe}(\mathrm{CN})_{6}^{-4}$ recovery and percent cesium removal from U-Plant 2 flowsheet samples are shown in Table 3.2. The level of cesium removal for the mesh size 20-50 (DF $\leq 50$ ) is less than that for the mesh size 100-200 material (DF >100). Although both mess sizes of ion exchange material remove a significant fraction of the cesium activity $(\geq 90 \%)$ from these simulant samples, the smaller particle size resin (mesh 100-200) has consistently much higher percent removal of cesium (>99\%). This value for cesium removal indicates that the activity from cesium can be reduced by more than an order of magnitude by one pass through the ion exchange column. The high ferrocyanide recovery (see Table 3.1 and supporting work in Section 4.0) indicates that the cesium removal technique will not interfere with the cyanide analysis. Since the percentage of cyanide recovered is not affected by different mesh sizes, the smaller mesh size (100-200) is recommended because it removes more cesium than the larger mesh size.

Table 3.2 Ferrocyanide Recovery and Cesium Removal From U-Plant Simulated Waste Using Ion Exchange

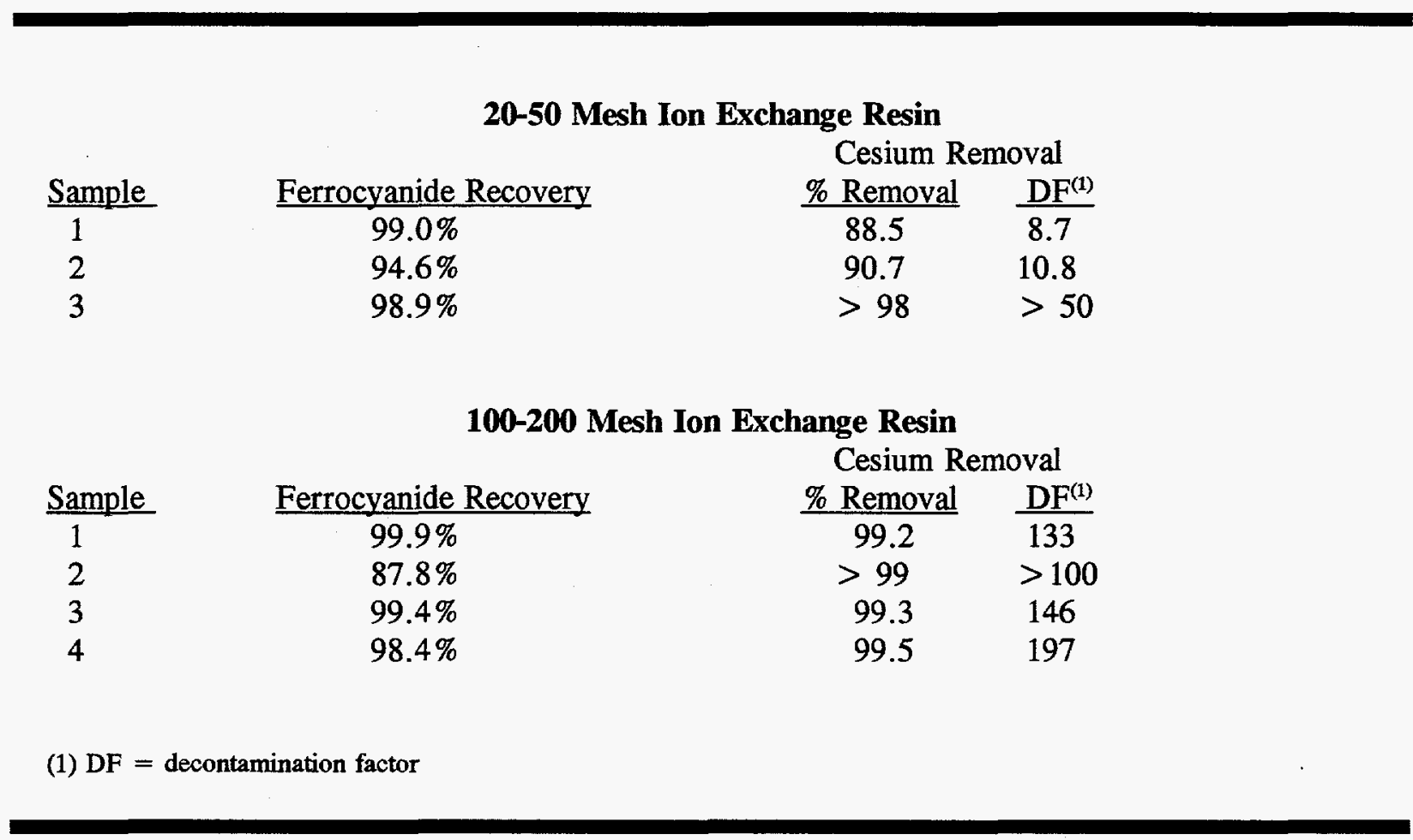




\subsection{Analysis of Actual Ferrocyanide Tank Waste}

Modifications of cesium ion exchange methods used for reducing the activity of ferrocyanide waste were completed and demonstrated on actual ferrocyanide waste samples from Tanks 241-C-112 and 241-C-109. Because the ${ }^{137} \mathrm{Cs}$ content in actual ferrocyanide tank samples, a need was identified to reduce personnel exposure to ALARA. To address this need we adapted existing methods for cesium ion removal currently performed on flammable gas tank waste (Campbell et al. 1994) to the ferrocyanide tank waste. This method was successfully demonstrated by removing significant levels of radioactivity from tank samples to allow the samples to be removed from the hot cell environment for bench-top handling. This will benefit the program in terms of reduced personnel exposure as well as time savings during actual sample manipulation and measurement. The details of this work are included in Section 4.1 .

Actual ferrocyanide waste samples from Tanks $241-\mathrm{C}-109$ and 241-C-112 were analyzed for cyanide content by FTIR, IC, and total cyanide methods. The radiocesium was removed by ion exchange prior to removing samples from the hot cells for FTIR and IC analysis. The total cyanide content was measured prior to and after ion exchange; the FTIR and IC methods were performed after ion exchange only. Excellent agreement was observed between these methods of analysis for the actual waste samples as discussed in Section 4.2.

Actual ferrocyanide waste samples from Tank $241-\mathrm{C}-112$ were repeatedly analyzed for cyanide content by FTIR, IC, and total cyanide (by microdistillation) methods. This sample was analyzed repeatedly to gain information on the robustness of the analytical techniques developed by this task. The radio-cesium was removed by ion exchange prior to removing samples from the hot cells for FTIR and IC analysis. The total cyanide content was measured prior to and after ion exchange, allowing for the recovery of ferrocyanide to be measured in this process. Cyanide measurements were performed by FTIR and IC methods after ion exchange and removal from the hot cell. The recovery of cyanide from the ion exchange process was excellent. The agreement observed between these three methods of analysis for the actual waste samples was also excellent. The spike recoveries measured for FTIR, microdistillation, and IC methods were $101.3 \%, 103 \%$, and $102.8 \%$ respectively. This work is included in Section 4.3.

\subsection{Reduction of Cesium from Actual Ferrocyanide Waste}

Ion exchange columns (described in Section 3.0) have been prepared and used for removal of radiocesium from actual waste samples in the PNL hot cells. BioRad AG 50w-x8, 100-200 mesh resin was used for cesium ion exchanges in all actual waste experiments. The samples listed in Table 4 are from archived Tank 241-C-112 and 241-C-109 samples. These samples were dissolved in the dissolution elixir previously described (Bryan et al. 1994). The actual waste samples were removed from the hot cells following the ion exchange procedure and were analyzed for the amount of ${ }^{137} \mathrm{Cs}$ within each sample. The decontamination factor as well as the percent ${ }^{137} \mathrm{Cs}$ removed from each sample are also listed in Table 4. The data in Table 4 indicate that significant levels of ${ }^{137} \mathrm{Cs}$ was removed from the actual ferrocyanide waste samples.

A gamma scan for a selected sample (241-C-109 241-C-49 Comp 1B) is shown in Figure 8. The relative counts for the solution measured before ion exchange are plotted along with the data measured for the same solution after ion exchange. The ${ }^{137} \mathrm{Cs}$ gamma peak $(0.662 \mathrm{MeV})$ is located on the gamma 
Table 4.1 ${ }^{137}$ Cs Concentrations and Decontamination Factors For Cesium Removal From Various Actual Tank Waste Samples [These samples were dissolved prior to analysis]

\begin{tabular}{|c|c|c|c|c|}
\hline \multicolumn{5}{|c|}{${ }^{137} \mathrm{Cs}, \mu \mathrm{Ci}$} \\
\hline Sample ID & Before IX ${ }^{(1)}$ & Post IX ${ }^{(1)}$ & $\underline{\mathrm{DF}}^{(2)}$ & ${ }^{137}$ Cs Removed \\
\hline C112 C34 Seg 2B & 3.02 & $5.14 \mathrm{E}-3$ & 143 & $99.3 \%$ \\
\hline C112 C34 Seg 2B & 3.58 & $1.07 \mathrm{E}-2$ & 82.3 & $98.8 \%$ \\
\hline C112 C34 Seg $2 C$ & 4.99 & $9.48 \mathrm{E}-3$ & 128 & $99.2 \%$ \\
\hline C112 C34 Seg $2 C$ & 4.27 & $8.57 \mathrm{E}-2$ & 12.3 & $91.9 \%$ \\
\hline C112 C36 Comp 2C & 8.08 & $3.13 \mathrm{E}-1$ & 6.3 & $84.2 \%$ \\
\hline C109 C49 Comp 1B & 0.454 & $4.77 \mathrm{E}-3$ & 23.8 & $95.8 \%$ \\
\hline C109 C49 Comp 1D & 4.14 & $9.89 \mathrm{E}-4$ & 1028 & $99.9 \%$ \\
\hline
\end{tabular}

(1) Before $\mathrm{IX}={ }^{137} \mathrm{Cs}$ concentration $(\mu \mathrm{Ci})$ before ion exchange, Post $\mathrm{IX}={ }^{137} \mathrm{Cs}$ concentration after ion exchange. These values were not corrected for dilution of the sample during ion exchange. The typical dilution factor is approximately 4.

(2) $\mathrm{DF}=$ decontamination factor. DF values were corrected for the dilution of the sample during ion exchange.

scan prior to ion exchange. The ${ }^{137} \mathrm{Cs}$ peak in the gamma scan after ion exchange is near baseline values.

\subsection{Actual Ferrocyanide Waste Analysis}

Actual ferrocyanide waste samples from Tanks $241-\mathrm{C}-109$ and $241-\mathrm{C}-112$ were analyzed for cyanide content. The radiocesium was removed by ion exchange prior to removing samples from the hot cells for FTIR analysis. The cyanide content of these samples was analyzed on the dissolved sample prior to ion exchange and on the solution after ion exchange by the total cyanide method. The post ion exchange samples were analyzed by the FTIR method as well.

The measured cyanide concentrations (based on original waste sample) for both the total cyanide method (before ion exchange) and FTIR method (after ion exchange) are shown in Table 4.2. The percent recovery of cyanide is also shown in Table 4.2. The percent recovery of cyanide from the ion exchange process is defined as follows

\section{\% CN Recovery from IX process $=(w t \% \mathrm{CN}$ after IX)/(wt\% $\mathrm{CN}$ before IX) $\times 100$}

where the wt\% $\mathrm{CN}$ after and before ion exchange (IX) is based on the original sample weight.

The cyanide percent recovery from the IX process for these waste samples ranges from 87 to $106 \%$. We reported erratic \% $\mathrm{CN}$ recoveries in a previous report which were based on total cyanide analyses of the after IX solutions which we now believe were in error. The correct amount of sulfuric acid "releasing solution" was not added to the analytical solutions after the IX step prior to distillation; this prevented the amount of dilution which takes place during the IX procedure. 


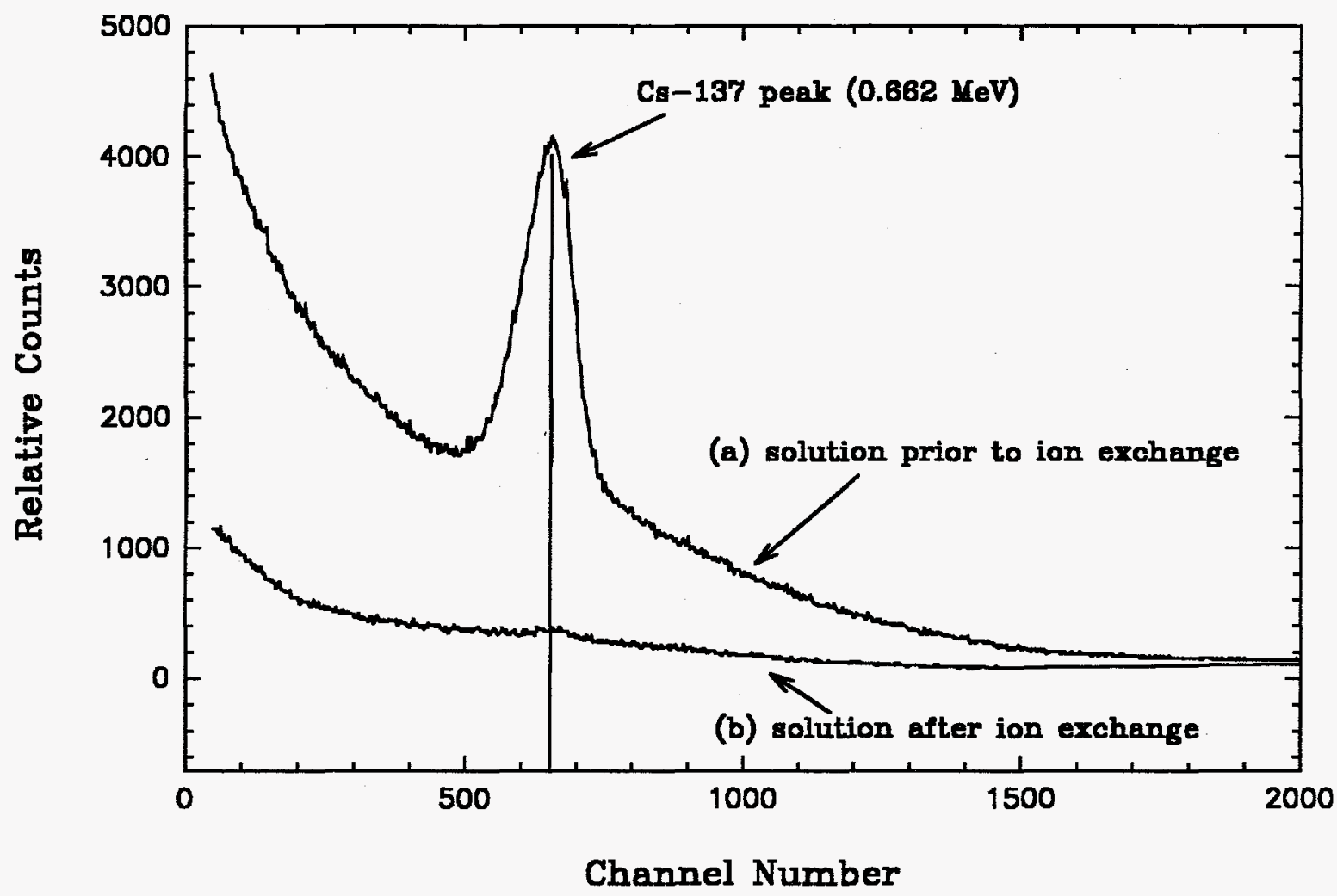

Figure 4.1 Gamma Scan for a Selected Actual Ferrocyanide Waste Sample (Tank 241-C-109, Core 49, Composite 1B) [Solution (a) is sample prior to ion exchange, solution (b) is sample after ion exchange]

The result was that the cyanide measurement of these samples by the distillation method was erroneously low. This would not, however, affect the analysis of these samples using the FTIR method.

The excellent agreement between these two methods (as indicated by the percent recovery in Table 4.2) demonstrates that the IX method does not affect recovery of cyanide and will not affect the analysis of cyanide in ferrocyanide waste samples.

An FTIR spectrum of an actual ferrocyanide waste sample (Tank 241-C-112, Core 36, Composite $2 \mathrm{C}$ ) is shown in Figure 4.2. This figure shows that the only cyanide species present in these solutions is the ferrocyanide complex (infrared peak located at $2038 \mathrm{~cm}^{-1}$ ). If there were other cyanide species present such as ferricyanide $\left(2116 \mathrm{~cm}^{-1}\right)$, free cyanide ion $\left(2080 \mathrm{~cm}^{-1}\right)$, nitroprusside (2141 and 1935 $\mathrm{cm}^{-1}$ ), etc., they would be observed in this spectrum. 
Table 4.2 Cyanide Concentrations and \% Cyanide Recovery From Various Actual Tank Waste Samples [These samples were dissolved in EDTA/en prior to analysis]

Sample ID

1 C112 C34 Seg 2B

$2 \mathrm{C} 112 \mathrm{C} 34$ Seg $2 \mathrm{C}$

3 C112 C34 Seg 2C

4 C112 C36 Comp 2C

5 C109 C49 Comp 1D wt\% $\mathrm{CN}^{1}$

Before IX

0.514

0.728

0.624

0.986

0.581 $\mathrm{wt} \% \mathrm{CN}^{2}$

After IX

0.520

0.732

0.664

0.859

0.599
\% Cyanide

Recovery

101.25

100.51

106.48

87.09

103.07

(1) Cyanide concentrations prior to $\mathrm{XX}$ were measured by the total cyanide method. Cyanide values are based on the wt\% $\mathrm{CN}^{-}$in the original sample.

(2) Cyanide concentrations after IX were measured using the FTIR method. Cyanide values are based on the wt\% $\mathrm{CN}^{-}$in the original sample.

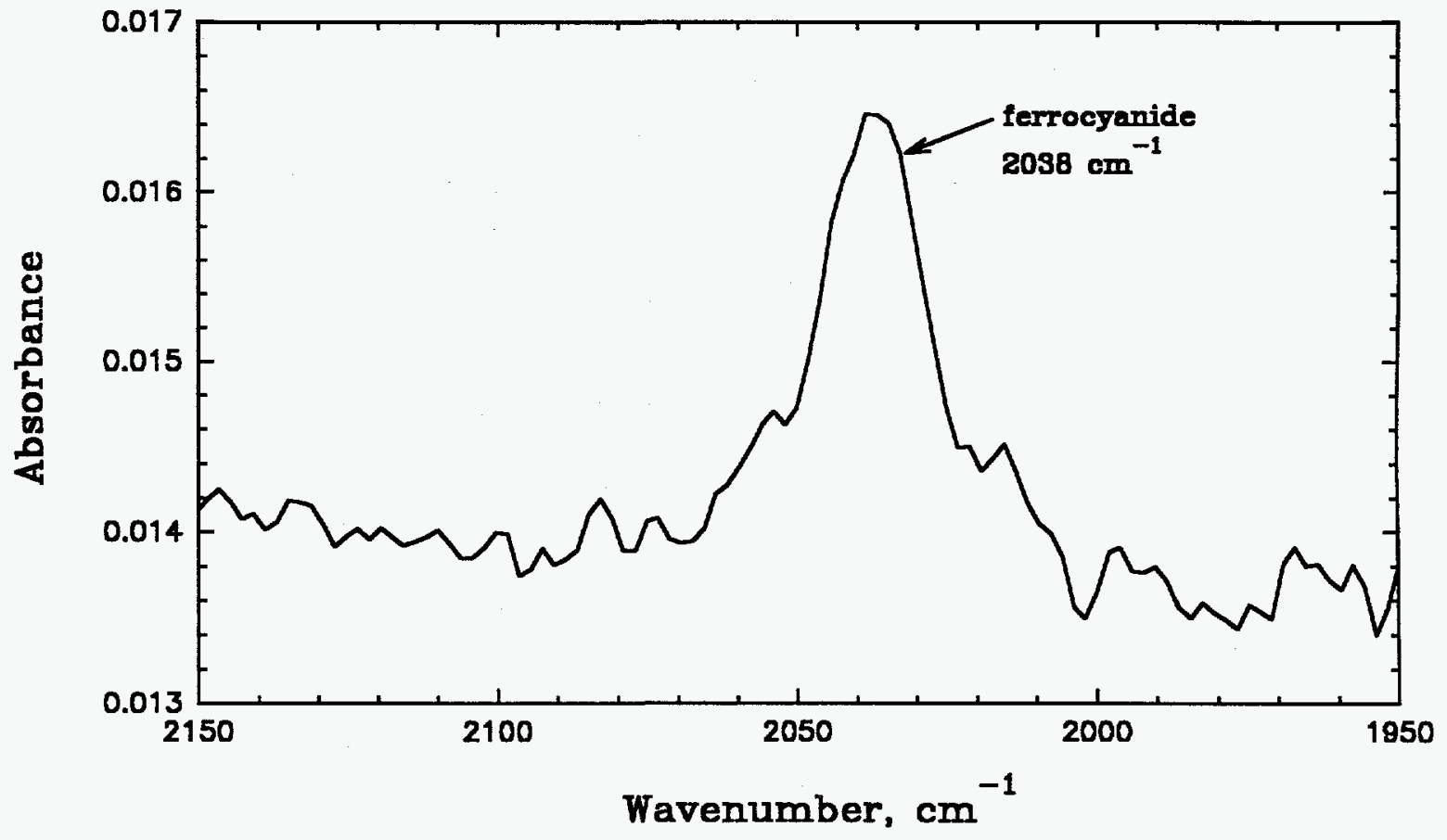

Figure 4.2 FTIR Spectrum of Actual Ferroyanide Waste Sample from Tank 241-C-112, Core 36, Composite $2 \mathrm{C}$ [This sample was dissolved in the EDTA/en elixir and passed through an ion exchange column prior to infrared analysis] 


\subsection{Comparison of Analyses of Tank 241-C-112 Ferrocyanide Waste Sample by Different Analytical Methods}

Actual ferrocyanide waste samples from Tank 241-C-112 were repeatedly analyzed for cyanide content by FTIR, IC, and total cyanide (by microdistillation) methods. This sample was analyzed repeatedly to gain information on the robustness of the analytical techniques developed by this task. The radio-cesium was removed by ion exchange prior to removing samples from the hot cells for FTIR and IC analysis.

The samples were all taken from a single dissolved solution of Tank 241-C-112 (Core 34, Segment 2D) ferrocyanide waste which was stored as archive \# 92-6739 in the PNL hot cell facility. This single-source sample was used for repeated analysis to establish the standard error for each analysis method as well as a valid comparison between the various methods used for cyanide measurements conducted on an actual ferrocyanide waste sample. This sample was analyzed by all methods within days of sample dissolution and preparation.

The measured cyanide concentrations (based on original waste sample) for the FTIR, IC and total cyanide methods are contained in Table 4.3. The percent recovery of cyanide from the ion exchange process was measured by analyzing the cyanide content of the ferrocyanide waste sample before and after the ion exchange process using the microdistillation method. The percent recovery of cyanide from the ion exchange process is described in Section 4.2. The cyanide recovery from ion exchange for these waste samples was measured to be $96.5+/-4.0 \%$. The high recovery of ferrocyanide from these waste samples indicates that the ion exchange method does not affect the recovery of cyanide and will not affect the analysis of cyanide in ferrocyanide waste samples.

In addition to the reported values in the Table 4.3 , blanks, spiked blanks, and matrix spikes were added to the suite of analyses. The results of the spike recoveries are also included in Table 4.3 as \% Spike Recovery. The agreement observed between these three methods of analysis for the actual waste samples is excellent; the differences between the average values are within the standard deviation of the measurements. The spike recoveries measured for FTIR, microdistillation, and IC methods are $101.3 \%, 103 \%$, and $102.8 \%$, respectively, indicating that no correction for cyanide loss within these methods is needed to be applied to the results.

The FTIR spectra of the actual ferrocyanide waste samples (Tank 241-C-112, Core 34, Segment 2D) were comparable to those observed from samples analyzed in Section 4.2 (see Figure 4.2). The only cyanide species observed in these solutions was the ferrocyanide complex (infrared peak located at $\left.2038 \mathrm{~cm}^{-1}\right)$. If other cyanide species were present, such as ferricyanide $\left(2116 \mathrm{~cm}^{-1}\right)$, free cyanide ion $\left(2080 \mathrm{~cm}^{-1}\right)$, nitroprusside $\left(2141\right.$ and $\left.1935 \mathrm{~cm}^{-1}\right)$, etc., they would have been observed in this spectrum. The absence of these bands indicates that the only solution species containing cyanide in this actual waste sample was the ferrocyanide complex, $\left[\mathrm{Fe}(\mathrm{CN})_{6}\right]^{4}$. The only species observed in the IC analysis was the ferrocyanide complex as well. 
Table 4.3 Comparison of Cyanide Concentrations Measured for Various Analytical Techniques. All concentrations are reported as wt\% cyanide in original sample.

\begin{tabular}{cccc} 
Material & \multicolumn{2}{c}{ Method (wt \% as CN-) } & \\
C112 Archive & FTIR & Microdistillation & IC \\
1 & 0.579 & 0.59 & 0.493 \\
2 & 0.496 & 0.57 & 0.498 \\
3 & 0.543 & 0.57 & 0.528 \\
4 & 0.545 & 0.54 & 0.523 \\
5 & 0.544 & $\mathrm{NA}$ & 0.552 \\
6 & 0.529 & 0.58 & 0.568 \\
7 & 0.567 & 0.58 & 0.516 \\
8 & 0.536 & 0.56 & 0.518 \\
Average & & & $0.524( \pm 0.025)$ \\
Spike Recovery & $101.3 \%$ & $0.57( \pm 0.016)$ & $102.8 \%$ \\
\hline
\end{tabular}




\subsection{Test Procedure to Determine Cyanide Species in Ferrocyanide Tank Waste Materials}

This section contains a draft test procedure for determining cyanide species from ferrocyanide flowsheet materials. This procedure will be used to identify concentrations of major cyanide species $\left[\mathrm{CN}^{-}, \mathrm{Fe}(\mathrm{CN})_{6}^{4-}\right.$, and $\left.\mathrm{Fe}(\mathrm{CN})_{6}^{3-}\right]$ expected in samples from the Hanford ferrocyanide waste tanks. These analytes were selected because they consist of most of the reasonable forms of cyanide possible, resulting from the initial addition of ferrocyanide to the ferrocyanide waste tanks. The methods are based on FTIR and IC. The overall detection limits for the relevant cyanide-containing species in the original undiluted waste are on the order of $0.1 \mathrm{wt} \%$ (as cyanide) for each method.

\section{Title of Procedure}

Determination of Free Cyanide and Cyanoferrate Species by FTIR and Reversed Phase IC Techniques

\section{Applicability}

This procedure provides methods for determining major cyanide-containing species $\left[\mathrm{Fe}(\mathrm{CN})_{6}^{3-}\right.$, $\mathrm{Fe}(\mathrm{CN})_{6}^{4-}, \mathrm{Fe}(\mathrm{CN})_{5} \mathrm{NO}^{2-}$, and $\left.\mathrm{CN}^{-}\right]$expected in samples from the ferrocyanide waste tanks. The overall detection limits for the relevant cyanide-containing species are on the order of $0.1 \mathrm{wt} \%$ each.

\section{Definitions}

\section{DIW Deionized water}

batch A group of samples of similar matrix processed at the same time

SST Single-shell tank

\section{Responsible Staff}

- Cognizant scientist

- Analyst/technician

\section{Procedure}

\section{Equipment and Materials}

- Analytical four-place balance

- FTIR spectrometer

- ATR circle cell, constructed with fluorocarbon wetted parts

- Plastic syringes $(5$ or $10 \mathrm{~mL}$ )

- Syringe filters

- Magnetic stirrer and disposable stir bars

- Scintillation vials with plastic insert caps

- High-performance liquid chromatograph system (HPLC) including high-pressure pump; eluant reservoirs; "reversed phase" column, with UV-vis or suppressed conductivity detector; and appropriate data display 


\section{Reagents}

Sample Pretreatment Solution: 5\% EDTA or HY $+5 \%$ ethylenediamine (en).

Weigh $5.0 \pm 0.1 \mathrm{~g}$ acid-form EDTA into $100-\mathrm{mL}$ volumetric flask. Add $\sim 60 \mathrm{~mL}$ DIW followed by $5.0 \pm 0.1 \mathrm{~g}$ en. Swirl to mix and dissolve solids. Adjust volume to mark with DIW. Store this solution in a labeled polybottle.

\section{$0.01 \mathrm{MNaOH}:$}

Dissolve $0.40( \pm 0.01) \mathrm{g} \mathrm{NaOH}$ pellets in $1.0 \pm 0.05 \mathrm{~L}$ of DIW.

\section{Chromatography Eluant:}

32.5 vol\% acetonitrile, $2 \mathrm{mM}$ tetrabutylammonium hydroxide, $0.6 \mathrm{mM} \mathrm{Na}_{2} \mathrm{CO}_{3}$.

\section{Stock Standard Solutions:}

$\mathrm{KCN}, \mathrm{K}_{3} \mathrm{Fe}(\mathrm{CN})_{6}, \mathrm{Na}_{4} \mathrm{Fe}(\mathrm{CN})_{6} \cdot 10 \mathrm{H}_{2} \mathrm{O}$ or $\mathrm{K}_{4} \mathrm{Fe}(\mathrm{CN})_{6}$, and $\mathrm{Na}_{2} \mathrm{Fe}(\mathrm{CN})_{5} \mathrm{NO} \cdot 2 \mathrm{H}_{2} \mathrm{O}$ dissolved in $0.01 \mathrm{~N} \mathrm{NaOH}$. Each stock standard solution should be approximately $1 \mathrm{wt} \%$ of cyanide and stored away from light in a laboratory refrigerator.

\section{Sample Pretreatment}

Weigh $1 \mathrm{~g}$ of sample $( \pm 0.001 \mathrm{~g})$ into a labeled scintillation vial. Add a disposable magnetic stir bar. Weigh $10 \mathrm{~g}$ pretreatment solution $( \pm 0.01 \mathrm{~g})$ into the vial. Stir for at least one-half hour to ensure complete dissolution of alkali metal-nickel-cyanoferrate compounds.

\section{Sample Analyses}

\section{FTIR:}

Warm up the instrument according to manufacturer's recommendation. Set the wave number display window to cover the 2200 to $1900 \mathrm{~cm}^{-1}$ region at a resolution of $8 \mathrm{~cm}^{-1}$ or higher while instrument is warming up and stabilizing. Prepare working calibration standards. Dilute stock standard solutions (described above) with sample pretreatment solution by weight. Prepare at least 4 calibration standards ( 1 of these may be a blank) that encompass the expected sample concentration range.

Inject the standards sequentially into the ATR cell using a plastic syringe (5 or $10 \mathrm{~mL}$ ) and in-line disposable syringe filter (if necessary). Develop the FTIR interferogram and record its transform for each standard. In a like manner, inject samples and spiked samples. Record all FTIR interferograms for later peak position identification and peak height (or area) determinations.

IC:

Warm up the instrument and allow it to stabilize for approximately one-half hour. If suppressed conductivity detection is used, make sure suppressor regenerate flow is adequate to reduce background conductivity to less than $10 \mu \mathrm{S} / \mathrm{cm}$. Prepare matrix-matched calibration of $\mathrm{Fe}(\mathrm{CN})_{6}^{4}$ and $\mathrm{Fe}(\mathrm{CN})_{6}{ }^{3-}$ and standards as described previously. Add solid $\mathrm{CaCO}_{3}(\sim 0.05 \mathrm{~g} / \mathrm{mL})$ to each calibra- 
tion standard and sequentially load instrument sample loop $(100 \mu \mathrm{L})$ by injection of each standard through $0.45-\mu \mathrm{m}$ syringe filter. In a like manner, inject samples and spiked samples. Record chromatographic peak areas (or peak heights) for later data analysis.

\section{Calculations - Data Analysis}

For either FTIR or IC data, prepare a calibration curve by plotting instrument response (peak area or peak height) versus concentration of standard for each analyte. Analyte concentrations in unknown samples and spiked samples are found by relating observed instrument responses to the calibration curve and multiplying by appropriate dilution factors, if any.

Spike recoveries (\% Recovery) are calculated from

$\%$ Recovery $=\frac{\text { wt. analyte found in spiked sample }- \text { wt. analyte found in sample alone }}{\text { wt. analyte spike added }} \times 100$

\section{Quality Control}

Each analytical session (batch processed) shall include as a minimum 1 method blank, 1 spiked sample, and 1 spiked blank (or control sample). For samples analyzed in support of SST characterization, duplicate analyses shall be performed for each. The control sample and spiking material should be prepared from available, well-characterized materials such as $\mathrm{Na}_{2} \mathrm{NiFe}(\mathrm{CN})_{6}$, In-Farm simulated waste, $\mathrm{K}_{3} \mathrm{Fe}(\mathrm{CN})_{6}, \mathrm{KCN}$, and/or $\mathrm{Na}_{2} \mathrm{Fe}(\mathrm{CN})_{5} \mathrm{NO} \cdot 2 \mathrm{H}_{2} \mathrm{O}$.

Spike recoveries or control sample recoveries outside the 85 to $115 \%$ range render suspect all results for the analytical session. The cognizant scientist shall investigate the situation and modify the procedure, if necessary, to restore observed recoveries to the acceptable range.

\section{Records}

Records pertaining to application of this procedure shall be managed and maintained according to QA Plan MCS-033 or its equivalent.

\section{Bibliography}

The following documents should be consulted to be familiar with this test procedure and instrumentation:

Bryan, S. A., K. H. Pool, L. L. Burger, C. D. Carlson, N. J. Hess, J. D. Matheson, J. L. Ryan, R. D. Scheele, and J. M. Tingey. 1993a. Ferrocyanide Safety Project, Task 3.5 Cyanide Species Analytical Methods Development, FY 1992 Annual Report. PNL-8399, Pacific Northwest Laboratory, Richland, Washington.

Bryan, S. A., K. H. Pool, S. L. Bryan, R. L. Sell, and L. M. P. Thomas. 1993b. Ferrocyanide Safety Program Cyanide Speciation Studies FY 1993 Report. PNL-8887, Pacific Northwest Laboratory, Richland, Washington.

Dionex Instrument Corporation Operation manual. 
Nicolet Instrument Corporation Operation manuals. 


\subsection{Status of Cyanide Speciation Studies}

This section summarizes the status of work performed within the Cyanide Speciation Task of the Ferrocyanide Safety Program. In FY 1995, we finalized the investigation of measuring the influence of chemical additives on the IC and FTIR analytical methods and adapted the FTIR analytical hardware into a radiation zone for handling radioactive samples. The analytical methods developed for measuring cyanide species using FTIR and IC have been demonstrated on actual ferrocyanide waste. The status of these activities is described below:

1. Influence of Chemical Additives on Cyanide Species Analysis. The simulant testing using IC methods was completed. The quantitative measurement for ferrocyanide and ferricyanide using IC techniques was extended to include the inorganic interferant ions, nitrate and nitrite.

2. Reduction of ${ }^{137} \mathrm{Cs}$ Content in Actual Waste Samples to Address ALARA Concerns. Because the ${ }^{137} \mathrm{Cs}$ content in actual ferrocyanide tank samples, a need was identified to reduce personnel exposure to ALARA. To address this need we adapted existing methods for cesium ion removal currently performed on flammable gas tank wastes (Campbell et al. 1994) was adapted to the ferrocyanide tank wastes. This method was successfully demonstrated for removal of significant levels of radioactivity from tank samples to allow the samples to be removed from a hot cell environment for bench-top handling. This will benefit the program in terms of reduced personnel exposure as well as time savings during actual sample manipulation and measurement.

3. Demonstration of FTIR and IC Analytical Methods on Actual Ferrocyanide Tank Wastes. Actual ferrocyanide waste samples from Tanks 241-C-109 and 241-C-112 were analyzed for cyanide content by FTIR, IC, and total cyanide methods. The radiocesium was removed by IX prior to removing samples from the hot cells for FTIR and IC analysis. The total cyanide content was measured prior to and after IX; the FTIR and IC methods were performed after IX only. Excellent agreement was observed between these methods of analysis for the actual waste samples. 


\subsection{References}

Bryan, S. A., K. H. Pool, S. L. Bryan, R. L. Sell, and L. M. P. Thomas. 1993.

Ferrocyanide Safety Program Cyanide Speciation Studies FY 1993 Report. PNL-8887, Pacific Northwest Laboratory, Richland, Washington.

Bryan, S. A., K. H. Pool, S. L. Bryan, B. D. Lerner, R. L Sell, and L. M. P. Thomas. 1994. Ferrocyanide Safety Program: Cyanide Speciation Studies - FY 1994 Annual Report. PNL-10151, Pacific Northwest Laboratory, Richland, Washington.

Burger, L. L. 1984. Complexant Stability Investigations. Task 1. Ferrocyanide Solids. PNL5441, Pacific Northwest Laboratory, Richland, Washington.

Burger, L. L., and R. D. Scheele. 1988. Interim Report on Cyanide Safety Studies. PNL7175, Pacific Northwest Laboratory, Richland, Washington.

Burger, L. L., and R. D. Scheele. 1990. The Reactivity of Cesium Nickel Ferrocyanide Towards Nitrate and Nitrite Salts. PNL-7550, Pacific Northwest Laboratory, Richland, Washington.

Burger, L. L., D. A. Reynolds, W. W. Schulz, and D. M. Strachan. 1991. A Summary of Available Information on Ferrocyanide Tank Wastes. PNL-7822, Pacific Northwest Laboratory, Richland, Washington.

Cady, H. H. 1993. Evaluation of Ferrocyanide/Nitrate Explosive Hazard. LA-12589-MS, Los Alamos National Laboratory, Los Alamos, New Mexico.

Campbell, J. A., S. Clauss, K. Grant, V. Hoopes, B. Lerner, R. Lucke, G. Mong, J. Rau, R. Steele. 1994. Flammable Gas Safety Program Analytical Methods Development: FY 1993 Progress Report. PNL-9062, Pacific Northwest Laboratory, Richland, Washington.

Dickinson, D. R., J. M. McLaren, G. L. Borsheim, and M. D. Crippen. 1993. Ferrocyanide Safety Program: Credibility of Drying Out Ferrocyanide Tank Waste by Hot Spots. WHC-EP0648, Westinghouse Hanford Company, Richland, Washington.

Epstein, M., H. K. Fauske, M. D. Crippen, D. R. Dickinson, J. D. McCormack, R. J. Cash, J. E. Meacham, and C. S. Simmons. 1994. Ferrocyanide Safety Program: An Assessment of the Possibility of Ferrocyanide Sludge Dryout. WHC-EP-0816, Westinghouse Hanford Company, Richland, Washington.

Hallen, R. T., L. L. Burger, R. L. Hockey, M. A. Lilga, R. D. Scheele, and J. M. Tingey. 1991. Ferrocyanide Safety Project FY 1991 Annual Report. PNL-8165, Pacific Northwest Laboratory, Richland, Washington. 
Hanlon, B. M. 1995. Waste Tank Summary Report for Month Ending May 31, 1995. WHCEP-0182-86, Westinghouse Hanford Company, Richland, Washington.

Hepworth, J. L., E. D. McClanahan, and R. L. Moore. 1957. Cesium Packaging Studies Conversion of Zinc Ferrocyanide to a Cesium Chloride Product. HW-48832, General Electric Company, Richland, Washington.

Jeppson, D.W., and J. J. Wong. 1993. Ferrocyanide Waste Simulant Characterization. WHC-EP-0631, Westinghouse Hanford Company, Richland, Washington.

Meacham, J. E., R. J. Cash, and G. T. Dukelow. 1995. Quarterly Report on the Ferrocyanide Safety Program for the Period Ending June 30, 1995. WHC-EP-0474-17, Westinghouse Hanford Company, Richland, Washington.

Peach, J. D. October 1990. Letter B-241479 to M. Synar, "Consequences of Explosion of Hanford's Single-Shell Tanks are Understated." GAO/RCED-91-34, General Accounting Office, Washington, D.C.

U.S. Department of Energy (DOE). 1987. Final Environmental Impact Statement, Disposal of Hanford Defense High-Level, Transuranic, and Tank Wastes. DOE-EIS-0113, U.S. Department of Energy, Washington, D.C.

Scheele R. D., and H. H. Cady. 1989. Preliminary Safe-Handling Experiments on a Mixture of Cesium Nickel Ferrocyanide and Equimolar Sodium Nitrate/Nitrite. PNL-7928, Pacific Northwest Laboratory, Richland, Washington.

Scheele, R. D., L. L. Burger, J. M. Tingey, S. A. Bryan, G. L. Borsheim, B. C. Simpson, R. J. Cash, and H. H. Cady. 1991. "Ferrocyanide Containing Waste Tanks: Ferrocyanide Chemistry and Reactivity." In Proceedings of Environmental Restoration '91, University of Arizona, Tucson, Arizona.

Scheele, R. D., L. L. Burger, J. M. Tingey, R. T. Hallen, and M. A. Lilga. 1992. "Chemical Reactivity of Potential Ferrocyanide Precipitates in Hanford Tanks with Nitrates and Nitrites." In Proceedings of Waste Management '92, University of Arizona, Tucson, Arizona. 


\section{Distribution}

No. of

Copies

\section{OFFSITE}

2 DOE/Office of Scientific and Technical Information

$7 \quad$ U.S. Department of Energy

EM-36, Trevion II

12800 Middlebrook Road

Germantown, MD 20874

ATTN: J. V. Antizzo, EM-36

C. O'Dell, EM-36 (5)

S. C. Grizzel, EH-15

C. Hilland

U.S. Department of Energy

656 Quince Diamond Road

Room 235, EM-20.1

Gaithersburg, MD 20879

T. C. Temple

U.S. Department of Energy

Savannah River Operations Office

P.O. Box A

Aiken, SC 29808

C. S. Abrams

1987 Virginia

Idaho Falls, ID 83404

D. O. Campbell

102 Windham Road

Oak Ridge, TN 37830

F. N. Carlson

6965 North 5th West

Idaho Falls, ID 83401

B. C. Hudson

202 Northridge Court

Lindsborg, KA 67456
No. of

Copies

W. R. Prindle

1556 Crestline Drive

Santa Barbara, CA 93105

A. Schneider

5005 Hidden Branches Drive

Dunwoody, GA 30338

G. E. Schmauch

Air Products \& Chemicals, Inc.

7201 Hamilton Blvd

Allentown, PA 18195-1501

K. K. Bandyopadhyay

Brookhaven National Laboratory

Upton, NY 11973

G. Powers

Design Science, Inc.

163 Witherow Road

Sewickley, PA 15143

2 Fauske and Associates, Inc.

16 W070 W. 83rd St.

Burr Ridge, IL 60521

ATTN: M. Epstein

H. K. Fauske

G. R. Choppin

Florida State University

Department of Chemistry B-164

Tallahassee, FL 32306

2 G\&P Consulting, Inc.

3640 Ballard Road

Dallas, OR 97338

ATTN: J. M. Grigsby

A. K. Postma

Distr. 1 
No. of

Copies

M. W. First

Harvard University

295 Upland Avenue

Newton Highlands, MA 02161

C. Grelecki

Hazards Research Corporation

200 Valley Road, Suite 301

Mt. Arlington, NJ 07856

3 Los Alamos National Laboratory

P.O. Box 1663

Los Alamos, NM 87545

ATTN: S. F. Agnew

S. W. Eisenhawer

T. E. Larson

M. S. Kazimi

MIT/Department of Nuclear Engineering 77 Massachusetts Ave.

Room 24-102

Cambridge, MA 02139

J. L. Kovach

Nuclear Consulting Services, Inc.

P.O. Box 29151

Columbus, OH 43229-0151

E. D. Collins

Oak Ridge National Laboratory

P.O. Box 2008

7930, MS-6385

Oak Ridge, TN 37831-6385

C. W. Forsberg

Oak Ridge National Laboratory

P.O. Box 2008

MS-6495

Oak Ridge, TN 37831-6495
No. of

Copies

T. S. Kress

Oak Ridge National Laboratory

P.O. Box 2009

9108, MS-8088

Oak Ridge, TN 37831-8088

A. S. Veletsos

Rice University

5211 Paisley

Houston, TX 77096

2 Sandia National Laboratories

P.O. Box 5800

Albuquerque, NM 87185

ATTN: D. A. Powers, MS-0744

S. E. Slezak, MS-0741

3 R. S. Daniels

Science Applications International

Corporation

20300 Century Blvd,

Suite 200-B

Germantown, MD 20874

M. T. Gordon

State of Washington

Department of Ecology

P.O. Box 47600

Olympia, WA $98504-7600$

A. Stone

State of Washington

Department of Ecology

1315 W. 4th Avenue

Kennewick, WA 99336

J. S. Byrd

University of South Carolina

Department of Electrical and Computer

Engineering

Swearingen Engineering Center

Columbia, SC 29208 
No. of

Copies

B. R. Kowalski

University of Washington

Center for Process Analytical Chemistry

Chemistry Department BG-10

Seattle, WA 98195

F. L. Parker

Vanderbilt University

P.O. Box 1596, Station B

Nashville, TN 37235

D. T. Oakley

Waste Policy Institute

555 Quince Orchard Road, Suite 600

Gaitherburg, MD 20878-1437

\section{ONSITE}

10 DOE Richland Operations Office

R. E. Gerton (2)

S7-54

R. G. Harwood

S7-54

W. F. Hendrickson

D. H. Irby (2)

A. G. Krasopoulos

Public Reading Room

RL Docket File (2)

35 Westinghouse Hanford Company

H. Babad

S7-30

J. B. Billetdeaux

S7-16

D. C. Board

W. S. Callaway

R. J. Cash (5)

M. D. Crippen

A4-81

H2-53

H5-36
No. of

Copies

R. D. Crowe

H0-38

D. R. Dickinson

L5-31

G. T. Dukelow

S7-15

M. N. Islam

R3-08

D. W. Jeppson

N. W. Kirch

L5-31

R2-11

C. A. Kuhlman

B3-30

E. J. Lipke

S7-14

L. L. Lockrem

S3-90

J. M. McLaren

H0-34

J. E. Meacham (2)

S7-15

N. J. Milliken

H4-62

S. R. Moreno

B3-06

T. V. Rebagay

T6-30

F. R. Reich

L5-63

E. F. Riedel

S3-90

B. C. Simpson

H. Toffer

R2-12

H0-38

W. T. Watson

H0-38

W. D. Winkelman

L5-55

W. D. Wittekind

H0-38

Central Files

EDMC

L8-04

H6-08

TFIC

R1-20

Pacific Northwest Laboratory

S. A. Bryan (20)

P7-25

P8-38

P.8-38

M. A. Lilga

P7-25

R. D. Scheele

K6-77

C. S. Simmons

K7-15

C. W. Stewart

P8-55 